\title{
Comprehensive Environmental Assessment of Potato as Staple Food Policy in China
}

\author{
Bing Gao ${ }^{1,2}$, Wei Huang ${ }^{1,3}{ }^{\circ}$, Xiaobo Xue ${ }^{4}$, Yuanchao Hu ${ }^{1,2}$, Yunfeng Huang ${ }^{5}$, Lan Wang ${ }^{1,3}$, \\ Shengping Ding ${ }^{1,3}$ and Shenghui Cui ${ }^{1,2, *}$ \\ 1 Key Lab of Urban Environment and Health, Institute of Urban Environment, Chinese Academy of Sciences, \\ Xiamen 361021, China \\ 2 Xiamen Key Lab of Urban Metabolism, Xiamen 361021, China \\ 3 University of Chinese Academy of Sciences, Beijing 100049, China \\ 4 Department of Environmental Health Sciences, State University of New York at Albany, NY 12144, USA \\ 5 School of Biotechnology Engineering, Jimei University, Xiamen 361021, China \\ * Correspondence: shcui@iue.ac.cn; Tel.: +86-592-6190777; Fax: +86-592-6190977
}

Received: 4 June 2019; Accepted: 20 July 2019; Published: 29 July 2019

check for updates

\begin{abstract}
The Chinese government projected 30\% of total consumed potatoes as a staple food (PSF) by 2020. We comprehensively assessed the potential impacts of PSF on rice and flour consumption, rice and wheat planting, energy and nutrient supply, irrigation-water, chemical nitrogen $(\mathrm{N})$, phosphorus pentoxide $\left(\mathrm{P}_{2} \mathrm{O}_{5}\right)$ and potassium oxide $\left(\mathrm{K}_{2} \mathrm{O}\right)$ fertilizer inputs and total greenhouse gases $(\mathrm{GHG})$ emission for potatoes, rice and wheat, by assuming different proportions of potato substitutes for rice and flour. The results showed that per capita, $2.9 \pm 0.3$ and $4.7 \pm 0.5 \mathrm{~kg}$ more potatoes per year would enter the Chinese staple-food diet, under the government's target. PSF consumed are expected to reach $5.2 \pm 0.7 \mathrm{Tg} \mathrm{yr}^{-1}$, equivalent to substituting potatoes for $4.2 \pm 0.8-8.5 \pm 0.8 \mathrm{Tg} \mathrm{yr}^{-1}$ wheat and $5.1 \pm 0.9-10.1 \pm 1.8 \mathrm{Tg} \mathrm{yr}^{-1}$ rice under different scenarios. While this substitution can increase the nutrient supply index by $63 \%$ towards nutrient reference values, it may induce no significant effect on staple-food energy supply with lower chemical fertilizer (except for $\mathrm{K}_{2} \mathrm{O}$ ) and irrigation-water inputs and GHG emissions in different substitution scenarios than the business as usual scenario. The reduction in rice and wheat demands lead to wheat in the North China Plain and early rice decrease by $6.1-11.4 \%$ and $12.1-24.1 \%$, respectively. The total GHG reduction is equal to $1.1-9.0 \%$ of $\mathrm{CO}_{2}$ equivalent associated with $\mathrm{CH}_{4}$ and $\mathrm{N}_{2} \mathrm{O}$ emitted from the Chinese agroecosystem in 2005. The saved irrigation water for three crops compared to 2012 reaches the total water use of $17.9 \pm 4.9-21.8 \pm 5.9$ million people in 2015. More N fertilizer, irrigation-water, and GHG can be reduced, if the PSF ratio is increased to $50 \%$ together with potato yield improves to the optimal level. Our results implied that the PSF policy is worth doing not only because of the healthier diets, but also to mitigate resource inputs and GHG emissions and it also supports agricultural structure adjustments in the areas of irrigated wheat on the North China Plain and early rice across China, designed to increase the adaptability to climate change.
\end{abstract}

Keywords: substitution ratio; chemical fertilizer inputs; irrigation-water use; total GHG emission; nutrient reference values

\section{Introduction}

Potatoes rank as the fourth largest food crop after rice, wheat and corn in the world, as well as in China. With a 400-year history of potato cultivation, China is now the world's largest potato producer. Planting area and yield reached 5.5 million ha and 19.0 million tons in 2013 [1], yielding approximately $20 \%$ of the world output [2]. However Chinese per capita consumption of potatoes was only $41 \mathrm{~kg}$ in 2011, ranking 65th in the world, far less than the per capita average of $84 \mathrm{~kg}$ in Europe and $185 \mathrm{~kg}$ in 
Belarus; the latter figure is equivalent to a Chinese resident's total annual consumption of wheat-flour staple foods [3]. In the EU and North America where one to two thirds of the daily potato consumption is in a processed form such as French fries and potato chips [4]. However the Chinese per capita annual consumptions of potato flour and potato chips are only about 73 and $15 \mathrm{~g}$, contributing to $0.4 \%$ and $0.2 \%$ of the total per capita potato consumption, respectively [5]. In other words, potatoes are mostly consumed as fresh vegetables in the current Chinese diet.

The Chinese government decided to promote potatoes as a staple food (PSF) in 2015, and set a target of $30 \%$ of the total potatoes consumed as a staple-food by 2020 [1], based on the following reasons, first, to meet the public's demand for tasty and healthful food [5], and the dietary needs of the fast-paced 21st-century lifestyle of both urban and rural residents [6]. Second, potatoes can become a major alternative crop in the agricultural structural adjustment that is needed to respond to limited arable land and declining water availability, because they can be grown with less water, land and fertilizer than cereal crops. Most importantly, with population and economic growth, Chinese grain demand is expected to increase by $6.9 \%$ and $3.3 \%$ for rice and wheat by 2030 , respectively, relative to 2012 [7]. Due to the limitation on arable land expansion in China [8], producing more food might occur at the expense of increasing nutrient inputs if no other improvements in agronomic management are made [7]. This presents the challenge of producing more grains with fewer inputs while reducing environmental costs. Potato as a staple food could meet 500 million tons of the food needs anticipated by China's increasing population, if the planting acreage could reach 150 million $\mathrm{mu}\left(1 \mathrm{mu}=667 \mathrm{~m}^{2}\right)$ by 2020 [6]. The governments' goal is to process potatoes for adapting to the Chinese consumer's eating habits for staple foods such as bread, steamed bread, and noodles, thereby changing potatoes from a non-staple food to a staple one [1].

Recent literatures shed light on the understanding of the nexus of food-energy-water for tackling interdependencies among food, energy, and water security $[9,10]$; reducing greenhouse gas (GHG) emissions, risks of eutrophication and land use demand by dietary recommendations [11]; Revealing the multiple environmental benefits of animal food consumption by calculating the land-water-GHG-N burdens of per consumed calorie of various livestock categories, and presenting recommendations for reducing multiple environmental benefits by guiding dietary changes to lower consumption of animal-derived food and reduce consumption of the uniquely high resource demands of beef [12]. These findings highlight that the changes in final food consumption-the demand for food, diet changes and selective food consumption-may drive the changes in land use, water, energy, GHG, and $\mathrm{N}$ inputs or burdens.

Developing potatoes as a staple food would decrease the consumption of flour and rice. The resulting reduction in rice and flour would lead to less wheat and rice planting-one of the goals of the agricultural structural adjustment in some regions of China. Potatoes have different chemical nitrogen $(\mathrm{N})$, phosphorus pentoxide $\left(\mathrm{P}_{2} \mathrm{O}_{5}\right)$ and potassium oxide $\left(\mathrm{K}_{2} \mathrm{O}\right)$ fertilizer and irrigation-water inputs and use efficiencies, and significant lower GHG emissions, compared with rice and wheat (see Supplementary Materials for details and Table S1). Many studies were conducted, mainly focusing on the current status of the consumption of potato and its related products in Chinese residents during 2010-2012 [5], a certain amount of potato flour addition could improve the quality of wheat flour and noodle [13], potatoes steamed bread as staple foods improved the nutrition structure of a Chinese resident by significantly enhancing vitamin $\mathrm{C}$, potassium, protein and dietary fiber [3], and GHG emissions, expressed in the form of a $\mathrm{CO}_{2}$ equivalent $\left(\mathrm{CO}_{2}\right.$-eq) from agricultural inputs in potatoes production are significantly lower than that in wheat and maize cultivation [14]. However, the shortage of integrated research remains, in particularly in quantifying the potential impacts of PSF on rice and flour consumption, rice and wheat production, resources input and total GHG emissions for rice, wheat and potatoes production behind the changes in staple food structure when potatoes entered into staple diets in China. The comprehensive evaluation of the impacts of potato staple food policies on multiple resource inputs, environmental indicators and food energy supplies are paramount for food security, cleaner production and sustainability of food production in China. 
This study aimed (1) to analyze the future trends in per capita staple-food and potato consumptions in 2020 based on the historical trends from 1980 to 2012; (2) to evaluate the comprehensive effects of PSF on the nexus of staple food consumption and production, chemical fertilizer and irrigation water inputs, total GHG emissions, food energy supply, nutrition structure, by assuming different proportions of potato substitutes for rice and wheat flour; (3) to assess the spatial patterns of potato systems substitute for winter wheat in the North China Plain (NCP) and early rice across China. These findings will help to explore solutions to produce more staple food with lower inputs and with reduced environmental costs in China and may provide a reference template for sustainable water management studies in the areas with serious water deficit.

\section{Methodology}

\subsection{Data Collection}

The datasets about urban and rural population, the selected cropping systems sowing area, per capita habitual staple food consumption were mainly taken from China's statistical yearbooks and bulletins and the Ministry of Health in China [15-17]. The second category of data is coefficients used for the calculation of the national chemical fertilizer inputs, irrigation-water consumption and total GHG emissions, e.g., the per hectare chemical N-, $\mathrm{P}_{2} \mathrm{O}_{5}$ - and $\mathrm{K}_{2} \mathrm{O}$-fertilizer and irrigation-water inputs, yield and their use efficiencies, power used per unit of irrigation rate and GHG emissions from different sources in early rice, medium rice, late rice, winter wheat in the NCP and winter wheat across China except for NCP and potato production (Tables S1-S5), were collected from the published literature between 2000-2017. The principle for collecting these data was that at least one of the indicators-such as chemical $\mathrm{N}-, \mathrm{P}_{2} \mathrm{O}_{5}$ - and $\mathrm{K}_{2} \mathrm{O}$-fertilizers, or irrigation-water input for the three crops-was reported. In total, 508 results were collected, which were divided between each of the cropping systems as follows; conventional potatoes (111) optimized potatoes (109), early rice (68), medium rice (44), late rice (48), winter wheat in the NCP (86) and winter wheat across China except for NCP (42; Tables S1, S2 and S5). The ratio of organic fertilizers' application area to total sown area is relatively low, especially in rice and wheat production, at the same time, the amounts of $\mathrm{N}_{2} \mathrm{P}_{2} \mathrm{O}_{5}$ and $\mathrm{K}_{2} \mathrm{O}$ from organic fertilizer were not directly reported in the selected literature as that of chemical fertilizers, and they can not be easy to calculate because the complex types of organic fertilizers and no available data on the contents of $\mathrm{N}, \mathrm{P}_{2} \mathrm{O}_{5}$ and $\mathrm{K}_{2} \mathrm{O}$ in some organic fertilizers. In addition, the organic $\mathrm{N}-, \mathrm{P}_{2} \mathrm{O}_{5}$ - and $\mathrm{K}_{2} \mathrm{O}$-fertilizers belong to the internal recycled resources in the food production-consumption system $[18,19]$, and we mainly emphasize the new resources input into the food system and evaluate the contribution of PSF to the national goal of zero growth in fertilizer use, hence, the $\mathrm{N}, \mathrm{P}_{2} \mathrm{O}_{5}$ and $\mathrm{K}_{2} \mathrm{O}$ sourced from organic fertilizers were excluded in this study. The mean partial factor productivities of chemical $\mathrm{N}$, $\mathrm{P}_{2} \mathrm{O}_{5}, \mathrm{~K}_{2} \mathrm{O}\left(\mathrm{PFP}_{\mathrm{N}}, \mathrm{PFP}_{\mathrm{P} 2 \mathrm{O} 5}\right.$ and $\mathrm{PFP}_{\mathrm{K} 2 \mathrm{O}}$, in kilograms of standard grain per kilogram of $\mathrm{N}_{2} \mathrm{P}_{2} \mathrm{O}_{5}$ and $\mathrm{K}_{2} \mathrm{O}$ applied) and irrigation-water use efficiencies (IWUE) for each crop were estimated by the yield divided by the relevant inputs (Tables S1 and S5). In addition, we calculated the mean irrigation rate for rice across China using early, medium and late rice irrigation amounts multiplied by each sown area, then divided by the total sown area for rice (Table S3).

GHG emissions from rice, wheat and potatoes production include soil $\mathrm{N}_{2} \mathrm{O}$ and $\mathrm{CH}_{4}$ emissions, the indirect $\mathrm{CO}_{2}$ from the manufacture and transportation of the chemical fertilizer, power use for irrigation, fuel combustion in farm operations, application of pesticide and film for mulching crops $[20,21]$. The detailed principle of collecting the above GHG emissions was described in SI Text. In total, 148 results of $\mathrm{N}_{2} \mathrm{O}$ and $\mathrm{CH}_{4}$ emissions were collected, which were divided between each of the cropping systems as follows; early rice (26), medium rice (22), late rice (41), wheat in the NCP (29), wheat across China except for NCP (24) and potatoes (6; Tables S1 and S2). We calculated the total GHG ( $\mathrm{kg} \mathrm{CO}_{2}$-eq ha ${ }^{-1}$ ) of different crops by summing all GHG emissions from soil and agronomy management, then calculated yield-scale GHG intensity (GHGI, $\mathrm{kg} \mathrm{CO}_{2}$-eq kg-1 grain) [20], for potatoes, winter wheat in the NCP and early rice across China. 


\subsection{Changes in Per Capita Staple-Food and Potato Consumption in China, 1980-2012, and Future Trends}

We collected per capita habitual staple-food (including rice, flour, other cereals, tubers and beans) intake data for Chinese urban and rural residents in 1982, 1992, 2002 and 2012 from the Ministry of Health in China $[15,16]$ (Table S6). We estimated per capita habitual food intake for the non-sampling years during the period 1980-2012, by linear interpolation between every two adjacent intervals of the surveys [22], and extrapolated per capita habitual staple-food intake for 2013-2020 based on the historical trends of each staple-food intake from 2002 to 2012, using a simply common trend projection method [23]. We then estimated per capita food consumption by urban and rural residents combined with the ratio of kitchen wastes (Table S7).

In 2012, per capita potato consumption values were 7.7 and $14.5 \mathrm{~kg} \mathrm{yr}^{-1}$ for urban and rural residents, respectively, accounting for $70 \%$ and $88 \%$ of per capita tuber (including mainly potatoes, sweet potatoes, yams and tania) consumption in urban and rural areas; however, as mentioned in introduction potatoes are mostly consumed as fresh vegetables in the current Chinese diet (Fang et al., 2016). We predicted the amounts of potatoes consumed as a vegetable in urban and rural populations in 2020 by historical trends of tuber consumption from 2002 to 2012, and assuming that the proportion of potatoes to other tubers keep constant as in 2012. Then the PSF consumption calculated with the following equation:

$$
\mathrm{SP}=\mathrm{VP} \times \mathrm{R}_{\mathrm{PSF}} /\left(1-\mathrm{R}_{\mathrm{PSF}}\right),
$$

where the $V P$ is potato-as-vegetable consumption amounts, the $R_{P S F}$ is the government's target of $30 \%$ of the total potatoes consumed as a staple-food, and we added $50 \%$ as an additional potential target (Table 1). The $V P$ was calculated as $6.7 \pm 1.0$ and $11.0 \pm 1.7 \mathrm{~kg} \mathrm{yr}^{-1}$ for urban and rural residents, respectively, in 2020.

Table 1. Potatoes-as-a-staple-food (PSF) ratios under different scenarios, with different proportions of potato substituted for rice and flour in China in 2020.

\begin{tabular}{cccc}
\hline Code & PSF Ratio & Substituted for Rice & Substituted for Flour \\
\hline BAU & $30 \%$ & 0 & 0 \\
$30 \%$ Scenarios & & 0 & $100 \%$ \\
$30 S_{0 \mathrm{R}+100 \mathrm{~F}}$ & $30 \%$ & $50 \%$ & $50 \%$ \\
$30 \mathrm{~S}_{50 \mathrm{R}+50 \mathrm{~F}}$ & $30 \%$ & $100 \%$ & 0 \\
$30 \mathrm{~S}_{100 \mathrm{R}+0 \mathrm{~F}}$ & $30 \%$ & 0 & $100 \%$ \\
$50 \%$ Scenarios & & $50 \%$ & $50 \%$ \\
$50 \mathrm{~S}_{0 \mathrm{R}+100 \mathrm{~F}}$ & $50 \%$ & $100 \%$ & 0 \\
$50 \mathrm{~S}_{50 \mathrm{R}+50 \mathrm{~F}}$ & $50 \%$ & $50 \%$ & \\
$50 \mathrm{~S}_{100 \mathrm{R}+0 \mathrm{~F}}$ & 50 & \\
\hline
\end{tabular}

BAU: business as usual.

\subsection{Scenario Analysis}

For the business as usual (BAU) scenario, we assumed a Chinese population of 1.44 billion people with an urbanization level of $60 \%$ in 2020 [24,25], and that per capita rice, flour and potato-as-vegetable consumptions changed at the same rate as historical trends during 2002-2012; the PSF consumption had no effect on the rice-or flour-as-staple-food consumptions; the production efficiencies of chemical $\mathrm{N}-, \mathrm{P}_{2} \mathrm{O}_{5}$ - and $\mathrm{K}_{2} \mathrm{O}$-fertilizers and irrigation water, and GHG emissions of rice, wheat and potatoes were the mean levels of the collected data in this study (Tables S1-S5), which can represent the mean pattern of farmers' practices in the last three decades and the near future as much as possible, hence we assumed that these efficiencies and GHGI of three crops no variation in all scenarios, and potato planting reached 6.7 million ha that has been proposed by the government [1]. For PSF scenarios, we adopted the Chinese government's target of having 30\% of total consumed potatoes as a staple food by 2020, and set a more ambitious target of increasing the proportion of PSF to $50 \%$. We further divided several sub-scenarios by assuming different proportions of potato substitutes for rice and 
flour (Table 1). Amounts of per capita consumption of PSF, under these different scenarios, were calculated according to the PSF consumption ratio and the per capita potato-as-vegetable consumption ratio in 2020 (Table 2). We then estimated the national PSF consumption under the different scenarios, by multiplying the population of rural and urban residents with the per capita PSF consumption in 2020 , and estimated the consumptions of rice and flour, and the demand for rice and wheat grain, fertilizer and irrigation-water inputs and GHG emissions for three crops under the different scenarios (Table S8), based on an equivalent replacement for rice and flour using potato powder [1,3]. The detailed information on the calculations of the demand for rice and wheat grain, fertilizer and irrigation-water inputs and GHG emissions under different scenarios are described in the SI text. We further compared the total energy supply between different potato substitutions for rice and flour scenarios and only rice and flour scenario in 2012, expressed as calorie (Table S9); and compared the nutrient supply index between $35 \%$ potato bread $(250 \mathrm{~g})$ and $100 \%$ wheat bread $(250 \mathrm{~g})$, which was calculated by the ratio between the provide nutrition from $35 \%$ potato bread $(250 \mathrm{~g})$ and $100 \%$ wheat bread $(250 \mathrm{~g})$ and nutrient reference values (NRV) given by the association of China dietary nutrition, multiply by the average weight of 14 nutrient index (includes crude protein, crude fiber, Vitamin $B_{1}$, Vitamin $B_{2}$, Vitamin C, potassium (K), phosphorus $(\mathrm{P})$, magnesium $(\mathrm{Mg})$, calcium $(\mathrm{Ca})$, (tellurium) Te, zinc $(\mathrm{Zn})$, manganese (Mn), copper ( $\mathrm{Cu}$ ) and selenium (Se); Table S10). The nutrient supply index can represent the extent of each nutrient supply close to the NRV, and we used the sum of these indices to evaluate the health effect of substitution PSF for rice and flour.

Table 2. Required per capita potato-as-vegetable (VP) and potato-as-a-staple food (PSF) consumptions, under the goals of $30 \%$ and $50 \%$ of PSF consumption in China's urban and rural areas in 2020.

\begin{tabular}{ccccc}
\hline \multirow{2}{*}{ Area } & \multirow{2}{*}{ Ratio of PSF/(VP+PSF) } & VP & PSF & VP + PSF \\
\cline { 3 - 5 } & & \multicolumn{3}{c}{ kg cap. $^{-\mathbf{1}} \mathbf{~ y r}^{-\mathbf{1}}$} \\
\hline \multirow{2}{*}{ Urban } & $30 \%$ & $6.7 \pm 1.0$ & $2.9 \pm 0.4$ & $9.6 \pm 1.1$ \\
& $50 \%$ & $6.7 \pm 1.0$ & $6.7 \pm 1.0$ & $13.5 \pm 1.4$ \\
Rural & $30 \%$ & $11.0 \pm 1.7$ & $4.7 \pm 0.7$ & $15.7 \pm 1.8$ \\
& $50 \%$ & $11.0 \pm 1.7$ & $11.0 \pm 1.7$ & $22.1 \pm 2.3$ \\
\hline
\end{tabular}

\subsection{Effect of PSF on Rice and Wheat Production in Different Scenarios}

The spatial patterns of early rice, winter wheat and potato systems at the county-level (Figure S1), were developed from a $30 \mathrm{~m} \times 30 \mathrm{~m}$ resolution land use map provided by Wu et al. [26] (see Supplementary Materials for details). Winter wheat in the NCP was further divided into irrigated(NCP-I) and rain-fed winter wheat (NCP-R) depended on their irrigation conditions [27]. Substituting rice and flour with potatoes as staple foods means we could cut down rice and wheat planting in China. In this study, we assumed rice reduction only in early rice planting, because it has lower yield and quality compared to medium and late rice. We also assumed that the decrease in winter wheat sowing would occur in the NCP, because this region is facing rapid depletion of groundwater due to the planting of winter wheat needs for excessive ground water for irrigation $[28,29]$. The reductions of early rice and winter wheat in the NCP were calculated by the substituting rice and wheat grain with potatoes, divided by per unit area yield of early rice across China and winter wheat in the NCP.

\subsection{Variability and Uncertainty Analysis}

There are uncertainties in estimating different staple food consumption, national chemical N-, $\mathrm{P}_{2} \mathrm{O}_{5}-, \mathrm{K}_{2} \mathrm{O}$-fertilizer and irrigation water inputs, total GHG emissions, etc. driven by the variability of the collected coefficient data on per hectare fertilizer and irrigation inputs, all GHG emission from soil and agronomy management, and activity data from China's Statistical Yearbook and the Ministry of Health in China, such as crop sowing area, per capita habitual staple food consumption and human population, urbanization rate. We calculated the mean and variation with the 90th percentile confidence interval of the collected data on per hectare fertilizer and irrigation inputs, all GHG emission from 
soil and agronomy management, as cited in Table S1 to Table S5, and assumed that uncertainties in results driven from activity data are within a range of $\sim 5 \%[19,30]$, such as rice, wheat and potato sown area, human population and urbanization rate. The per capita potatoes consumption [5], the per capita habitual staple food consumption from the Ministry of Health in China, the predicted the amounts of tuber consumed as a vegetable in urban and rural populations in 2020 by historical trends of tuber consumption from 2002 to 2012, per capita water consumption in 2015 [31], and the predicted population of 2020 given by Wang et al. [24], and we assumed that these data will drive $10 \%$ uncertainties for our results. An uncertainty analysis was performed using the error propagation equation of mathematical statistics [32] (see Supplementary Materials for details). The means and likely ranges are reported in associate contents, figures and tables.

\section{Results}

\subsection{Variations in Staple Food Consumption Per Capita and Its Composition}

Per capita staple-food consumption, and the contributions of each food type to the total staple-food consumption in Chinese urban and rural households, dramatically changed during 1980-2012 (Figure 1). In the urban setting, total staple-food consumption per capita fell steadily from $223.6 \pm 13.1$ to $131.0 \pm 7.7 \mathrm{~kg} \mathrm{cap} .^{-1} \mathrm{yr}^{-1}$, but the decrease rate slowed after the year 2002, because small increases in the consumptions of flour and other cereals offset the decreases in the consumption of rice, tubers and beans. The consumption of tubers, including mainly potatoes, sweet potatoes, yams and tania, showed a decrease from 27.0 to $10.9 \mathrm{~kg} \mathrm{cap} .{ }^{-1} \mathrm{yr}^{-1}$. Rice and flour together accounted for more than $80 \%$ of total staple food consumption, followed by potatoes, other cereals, beans and tubers (excluding potatoes), whose shares were $6 \%, 5 \%, 4 \%$ and $3 \%$ in 2012, respectively. In the rural setting, total staple-food consumption per capita has followed the same trend as in the urban setting, decreasing from $329.5 \pm 16.5$ to $183.1 \pm 11.5 \mathrm{~kg} \mathrm{cap}^{-1} \mathrm{yr}^{-1}$; rice showed an increase in the $1980 \mathrm{~s}$, and then fell to about $99.0 \mathrm{~kg} \mathrm{cap}^{-1} \mathrm{yr}^{-1}$ in the 2010s. Flour showed the same trend as rice, maintaining at roughly $55.0 \mathrm{~kg} \mathrm{cap.} .^{-1} \mathrm{yr}^{-1}$ in the 2010s. As for other cereals and tubers, they clearly decreased, from 70.3 and $97.7 \mathrm{~kg} \mathrm{cap}^{-1} \mathrm{yr}^{-1}$ in 1980 to 7.8 and $16.4 \mathrm{~kg} \mathrm{cap}^{-1} \mathrm{yr}^{-1}$ in 2012, respectively. The proportions of rice accounted for $28-54 \%$ of staple food consumption during 1980 to 2012 , while flour increased from $19 \%$ to $30 \%$, and other cereals and tubers showed a dramatic reduction, from $21 \%$ and $30 \%$ to $5 \%$ and $9 \%$, respectively. The per capita rice and flour consumption amounts were predicted to reach 50.7 and $49.8 \mathrm{~kg} \mathrm{yr}^{-1}$ for urban residents, and 98.1 and $55.6 \mathrm{~kg} \mathrm{yr}^{-1}$ for rural residents, respectively, in 2020, based on their trends during 2002-2012. Together, they accounted for $82 \%$ and $88 \%$, respectively, of the per capita total staple-food consumption in urban and rural areas.

If the targets of $30 \%$ and $50 \%$ of the total PSF consumption (additional annual per capita consumptions of more than $2.9 \pm 0.4$ and $6.7 \pm 1.0 \mathrm{~kg} \mathrm{yr}^{-1}$ for urban areas, and $4.7 \pm 0.7$ and $11.0 \pm 1.7 \mathrm{~kg} \mathrm{yr}^{-1}$ for rural areas, respectively) are achieved, the potato will enter the Chinese diet as a staple food by 2020 (Table 2). The amounts of PSF currently account for $2.6 \%$ and $6.7 \%$, respectively, of the weight of rice and flour consumed in urban areas, and 3.1\% and 7.2\%, respectively, in rural areas. 

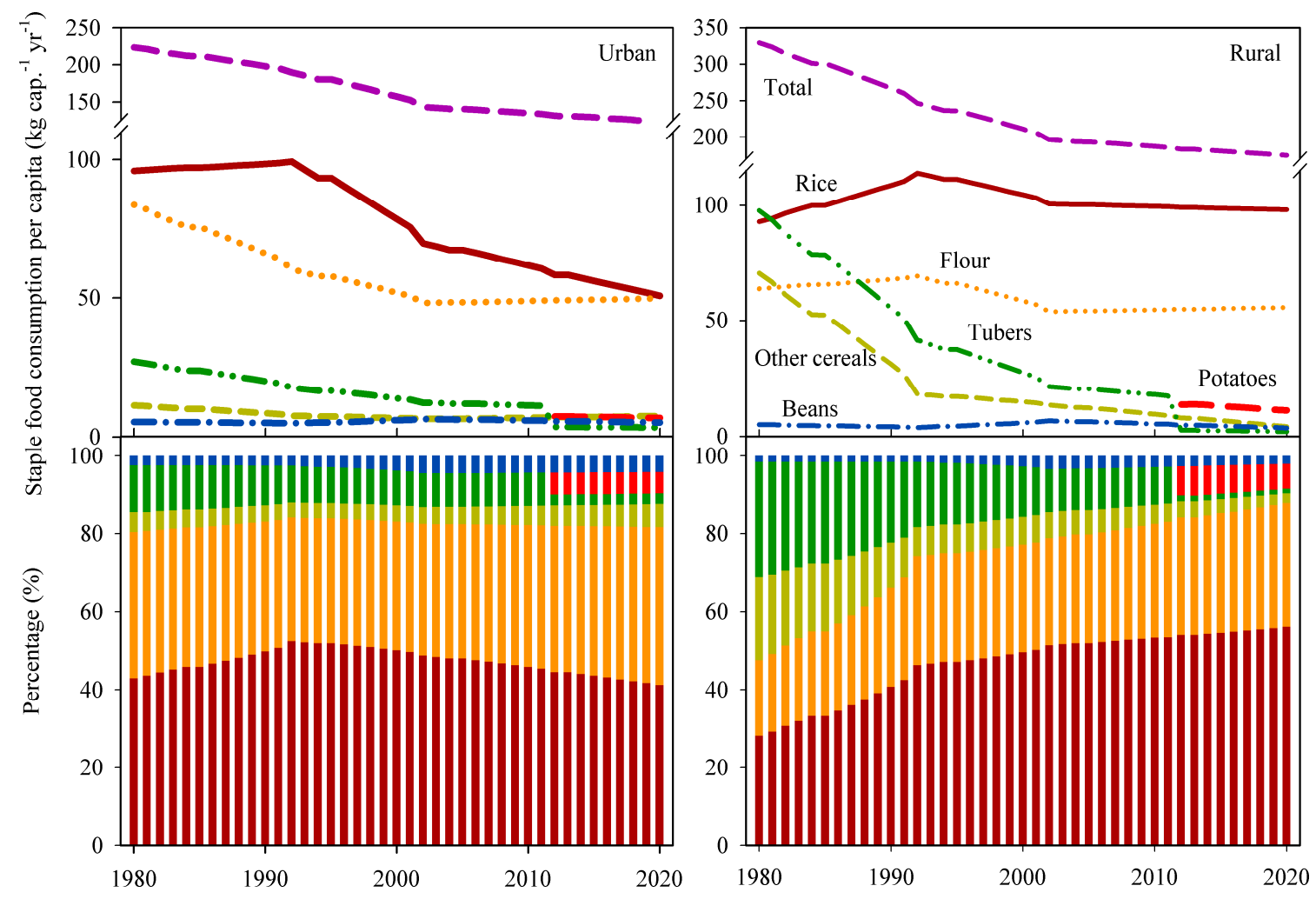

Figure 1. Staple-food consumption per capita and proportions in Chinese urban and rural households during 1980-2012, and projected future trends to 2020.

\subsection{Effect of PSF on Potatoes, Rice and Flour Consumption, and on Potatoes, Rice and Wheat Production under Different Scenarios}

In 2012, the national rice, flour and potatoes consumption was $189.5 \pm 12.6 \mathrm{Tg}$, including $105.1 \pm 10.5 \mathrm{Tg}$ rice, $70.3 \pm 7.0 \mathrm{Tg}$ flour and $14.1 \pm 0.7 \mathrm{Tg}$ potatoes (Figure 2). Under the BAU, the total consumption will increase to $192.4 \pm 19.8 \mathrm{Tg}$ by 2020 . However, rice consumption will decrease by $5.0 \pm 0.5 \mathrm{Tg} \mathrm{yr}^{-1}$, flour and potatoes consumption will increase by $4.6 \pm 0.4$ and $3.3 \pm 0.1 \mathrm{Tg}^{\mathrm{yr}^{-1}}$,

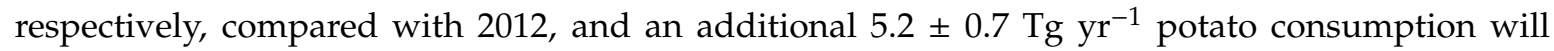
enter household diets as staple food. Under the 30\% scenarios, this $5.2 \pm 0.7 \mathrm{Tg}$ PSF can substitute

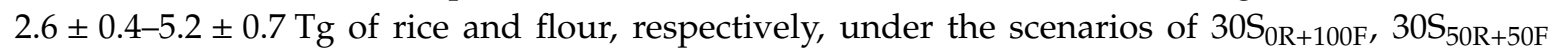
and $30 S_{100 R+0 F}$. Rice consumption would be maintained the same level as under the BAU if PSF completely replaced flour under the $30 \mathrm{~S}_{0 \mathrm{R}+100 \mathrm{~F}}$ scenario, while it would decrease by $2.6 \%$ for $30 \mathrm{~S}_{50 \mathrm{R}+50 \mathrm{~F}}$ and $5.2 \%$ for $30 S_{100 R+0 F}$ relative to the BAU. Flour consumption would be maintained at the same level as under the BAU if PSF completely substituted for rice under the $30 S_{100 R+0 F}$ scenario, while it would decrease by $3.5 \%$ for $30 \mathrm{~S}_{50 \mathrm{R}+50 \mathrm{~F}}$ and $6.9 \%$ for $30 \mathrm{~S}_{0 \mathrm{R}+100 \mathrm{~F}}$, relative to the BAU. Under the $50 \%$ scenarios, an additional $7.0 \pm 0.4 \mathrm{Tg} \mathrm{yr}^{-1}$ potato consumption would enter the household diet as a staple food relative to $30 \%$ scenarios, and could substitute for $6.1 \pm 0.9$ and $12.2 \pm 1.7 \mathrm{Tg}$ rice or flour $\mathrm{yr}^{-1}$, respectively, under the scenarios of $50 \mathrm{~S}_{0 \mathrm{R}+100 \mathrm{~F}}, 50 \mathrm{~S}_{50 \mathrm{R}+50 \mathrm{~F}}$ and $50 \mathrm{~S}_{100 \mathrm{R}+0 \mathrm{~F}}$. Rice consumption would decrease by $6.1 \%$ for $50 \mathrm{~S}_{50 \mathrm{R}+50 \mathrm{~F}}$ and $12.2 \%$ for $50 \mathrm{~S}_{100 \mathrm{R}+0 \mathrm{~F}}$ relative to the BAU, and flour consumption would decrease by $16.3 \%$ for $50 S_{0 R+100 F}$ and $8.1 \%$ for $50 S_{50 R+50 F}$ relative to the BAU. However, food energy supply in different potatoes substitution scenarios only increase by $0.4-1.6 \%$ compared to the only rice and flour scenario in 2012.

The potential effect of PSF on rice and wheat production was also estimated (Figure 3), by considering the relationships between initial grain production and the final rice and flour consumption by households. The results showed that the demand for rice would decrease by $4.6 \%$ under the BAU scenario, but the demand for wheat would increase by $6.6 \%$ over 2012 . Under the 
$30 \mathrm{~S}_{0 \mathrm{R}+100 \mathrm{~F}}$ and $50 \mathrm{~S}_{0 \mathrm{R}+100 \mathrm{~F}}$ scenarios, PSF could substitute for $8.5 \pm 1.5$ and $19.8 \pm 3.6 \mathrm{Tg}^{\mathrm{s}}$ wheat $\mathrm{yr}^{-1}$, respectively, accounting for $7.0 \%$ and $16.3 \%$ of China's wheat demand in 2020, under the BAU. Under the $30 \mathrm{~S}_{100 \mathrm{R}+0 \mathrm{~F}}$ and $50 \mathrm{~S}_{100 \mathrm{R}+0 \mathrm{~F}}$ scenarios, potatoes could substitute for $10.1 \pm 1.8$ and $23.7 \pm 4.3 \mathrm{Tg}$ rice grain $\mathrm{yr}^{-1}$, accounting for $5.2 \%$ and $12.2 \%$ of the rice demand in 2020 under the BAU. Under the $30 \mathrm{~S}_{50 \mathrm{R}+50 \mathrm{~F}}$ and $50 \mathrm{~S}_{50 \mathrm{R}+50 \mathrm{~F}}$ scenarios, potatoes could substitute for $4.2 \pm 0.8$ and $9.9 \pm 1.8 \mathrm{Tg}$ wheat $\mathrm{yr}^{-1}$, and $5.1 \pm 0.9$ and $11.8 \pm 2.1 \mathrm{Tg}$ rice $\mathrm{yr}^{-1}$, respectively. Substituting rice and winter wheat with potatoes may lead to land use change, such as converting early rice across China or irrigated winter wheat in the NCP to potato cultivation (Figure S1). Under the $30 \mathrm{~S}_{0 \mathrm{R}+100 \mathrm{~F}}$ and $50 \mathrm{~S}_{0 \mathrm{R}+100 \mathrm{~F}}$ scenarios, PSF could substitute $1.3 \pm 0.4 \times 10^{6}$ and $3.0 \pm 0.9 \times 10^{6}$ ha winter wheat sowing in the NCP, or $1.4 \pm 0.4 \times 10^{6}$ and $3.3 \pm 0.9 \times 10^{6}$ ha early rice could be substituted by potatoes in $30 \mathrm{~S}_{100 \mathrm{R}+0 \mathrm{~F}}$ and $50 \mathrm{~S}_{100 \mathrm{R}+0 \mathrm{~F}}$ scenarios. Under the $30 \mathrm{~S}_{50 \mathrm{R}+50 \mathrm{~F}}$ and $50 \mathrm{~S}_{50 \mathrm{R}+50 \mathrm{~F}}$ scenarios, potatoes could substitute for $0.7 \pm 0.2 \times 10^{6}$ and $1.5 \pm 0.4 \times 10^{6}$ ha winter wheat in the NCP, and $0.7 \pm 0.1 \times 10^{6}$ and $1.7 \pm 0.3 \times 10^{6}$ ha early rice across China, respectively.

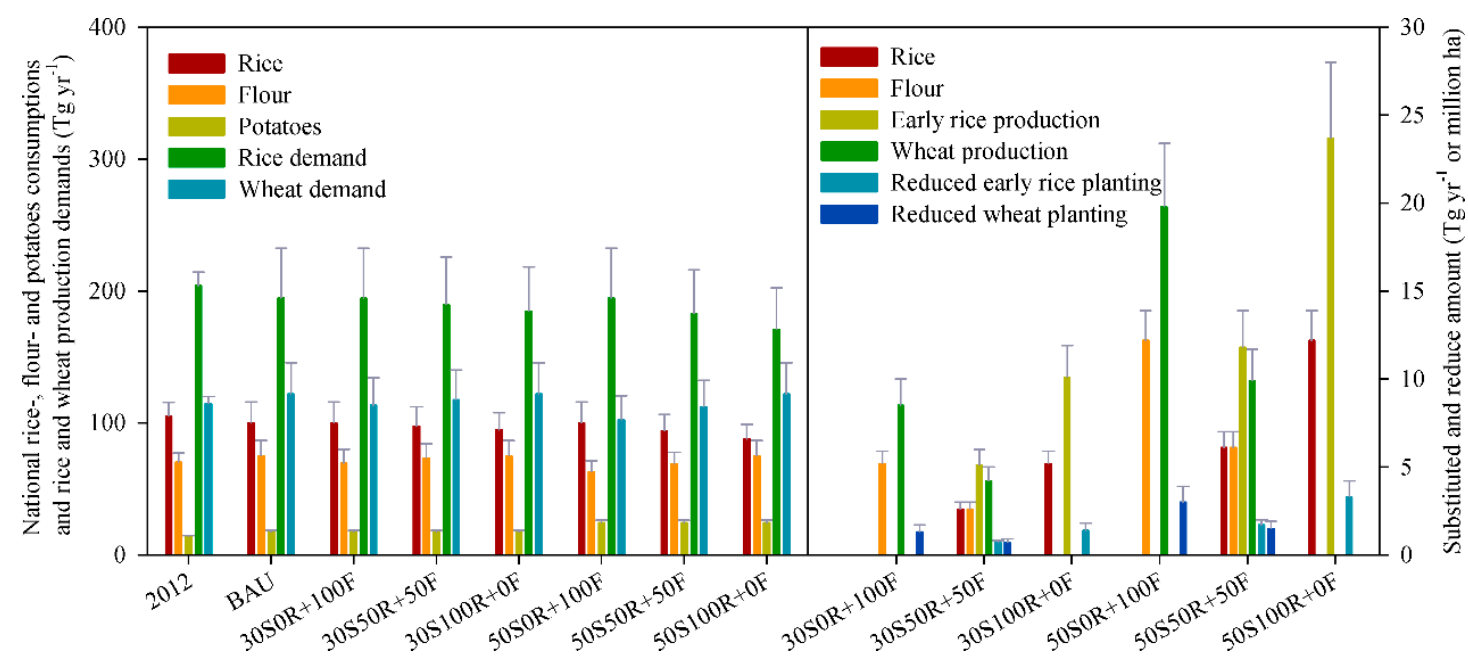

Figure 2. National rice-, flour- and potato consumptions; rice and wheat production demands $\left(\mathrm{Tg}_{r^{-1}}\right.$; left); potatoes as staple foods substituted for rice and flour, and rice and wheat production $\left(\mathrm{Tg} \mathrm{yr}^{-1}\right)$; reduced early rice and wheat planting (million ha) under the different substitution scenarios in 2020, in comparison with 2012 (right).

\subsection{GHG Emissions and GHGI for Producing Potatoes, Wheat and Rice}

The GHG emissions for producing potatoes in conventional and optimized practices, winter wheat in the NCP, winter wheat across China except for NCP, early rice, medium rice and late rice was $3636 \pm 1140,3323 \pm 1037,4677 \pm 2329,4212 \pm 1360,9138 \pm 5059,9943 \pm 3993$ and $11,393 \pm 3993 \mathrm{~kg} \mathrm{CO}_{2}$-eq ha ${ }^{-1}$, respectively (Figure 3). GHGI for producing potatoes in conventional and optimized practices, winter wheat in the NCP and early rice was $0.7 \pm 0.3,0.5 \pm 0.2,0.7 \pm 0.4$ and $1.3 \pm 0.7 \mathrm{~kg} \mathrm{CO}_{2}$-eq kg${ }^{-1}$, respectively. This result explained that the total GHG for producing staple food reduced when substituting rice and flour with potatoes. 


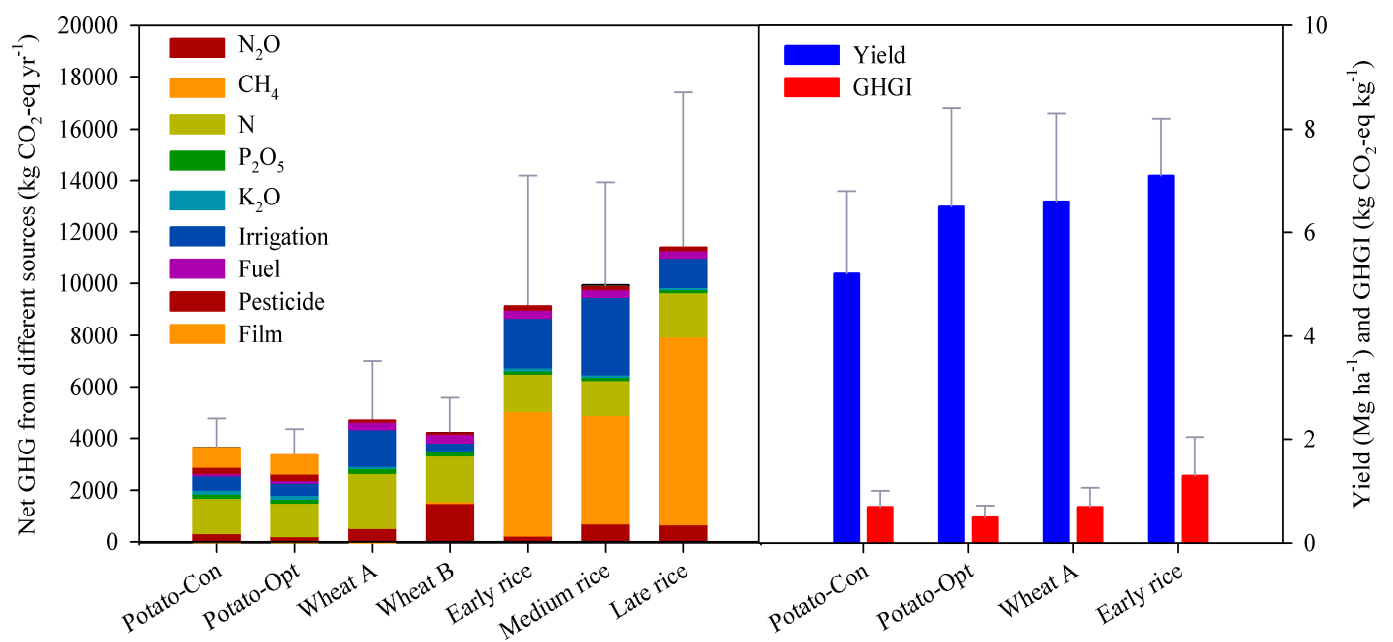

Figure 3. Total GHG emission from different $\mathrm{CO}_{2}$-eq emissions in conventionally grown (Potato-Con), and optimally grown (Potato-Opt) potatoes, winter wheat in the North China Plain (NCP; wheat A), winter wheat across China except for NCP (wheat B) and early, medium and late rice in China (left) and the yields and GHGI of Potato-Con, Potato-Opt, wheat A and early rice (right).

3.4. Total Chemical $\mathrm{N}-, \mathrm{P}_{2} \mathrm{O}_{5^{-}}$and $\mathrm{K}_{2} \mathrm{O}$-fertilizer, Irrigation-Water Consumption and total GHG Emissions for Producing Potatoes, Wheat and Rice

Total chemical $\mathrm{N}-, \mathrm{P}_{2} \mathrm{O}_{5}-$ and $\mathrm{K}_{2} \mathrm{O}$-fertilizer applications and irrigation-water used for the three crops were $11.9 \pm 3.7,5.6 \pm 0.6$ and $5.7 \pm 0.9 \mathrm{Tg} \mathrm{yr}^{-1}$ and $239.6 \pm 82.5 \times 10^{9} \mathrm{~m}^{3} \mathrm{yr}^{-1}$ under conventional practices in 2012 (Table S8). Under the BAU scenario, chemical N, $\mathrm{P}_{2} \mathrm{O}_{5}$ and $\mathrm{K}_{2} \mathrm{O}$ applications had smaller increases-by $0.2 \pm 0.05 \mathrm{Tg} \mathrm{yr}^{-1}$ - while irrigation-water decreased by $5.9 \pm 1.5 \times 10^{9} \mathrm{~m}^{3} \mathrm{yr}^{-1}$, under 2012 amounts (Figure 4). PSF scenarios have different effects on total chemical $\mathrm{N}, \mathrm{P}_{2} \mathrm{O}_{5}$ and $\mathrm{K}_{2} \mathrm{O}$ applications and irrigation-water use, when using potato substitutes for different proportions of rice and flour, because potatoes have different chemical fertilizers and irrigation-water inputs and use efficiencies with early rice across China and winter wheat in the NCP (Figure S2). Compared with BAU scenario increased chemical $\mathrm{N}_{2} \mathrm{P}_{2} \mathrm{O}_{5}$ and $\mathrm{K}_{2} \mathrm{O}$ applications for three crops under conventional practices, all the substitute scenarios mitigate $\mathrm{N}, \mathrm{P}_{2} \mathrm{O}_{5}$ and $\mathrm{K}_{2} \mathrm{O}$ applications, except for $\mathrm{K}_{2} \mathrm{O}$ applications in three $50 \%$ of potatoes as staple food scenarios, and irrigation water and GHG emissions further decreased. The total GHG was $427.1 \pm 96.3 \mathrm{Gg} \mathrm{CO}_{2}$-eq for producing potatoes, rice and winter wheat in 2012, and it decreased by $3.4 \pm 0.6 \mathrm{Gg} \mathrm{CO}_{2}$-eq in BAU scenario because of the reduction in rice consumption in 2020 relative to 2012. Under different substitution scenarios, total GHG can reduce by $9.4 \pm 1.7-23.3 \pm 3.8 \mathrm{Gg} \mathrm{CO}_{2}$-eq under conventionally grown potatoes and $14.1 \pm 2.5-32.6 \pm 2.5 \mathrm{Gg} \mathrm{CO}_{2}$-eq under optimally grown potatoes, compared to 2012. The highest reduction appeared in $50 \mathrm{~S}_{100 \mathrm{R}+0 \mathrm{~F}}$ scenario because of the higher GHGI of early rice than potatoes and winter wheat (Figure 3).

Potato yield in China was found to be $25.8 \mathrm{Mg} \mathrm{ha}^{-1}$, using conventional practices: $25.6 \%$ lower than if optimized practices were used. If the potato yields could be increased from the current conventional level to an optimized practices level, total chemical $\mathrm{N}, \mathrm{P}_{2} \mathrm{O}_{5}$ and irrigation-water use for three crops would be further decreased, compared to 2012, because of the higher two fertilizer use efficiencies and IWUE in optimized practices than in conventional practices (Figure S3). However, $\mathrm{K}_{2} \mathrm{O}$ application will slightly increase because potatoes like $\mathrm{K}_{2} \mathrm{O}$ more than rice and wheat. 


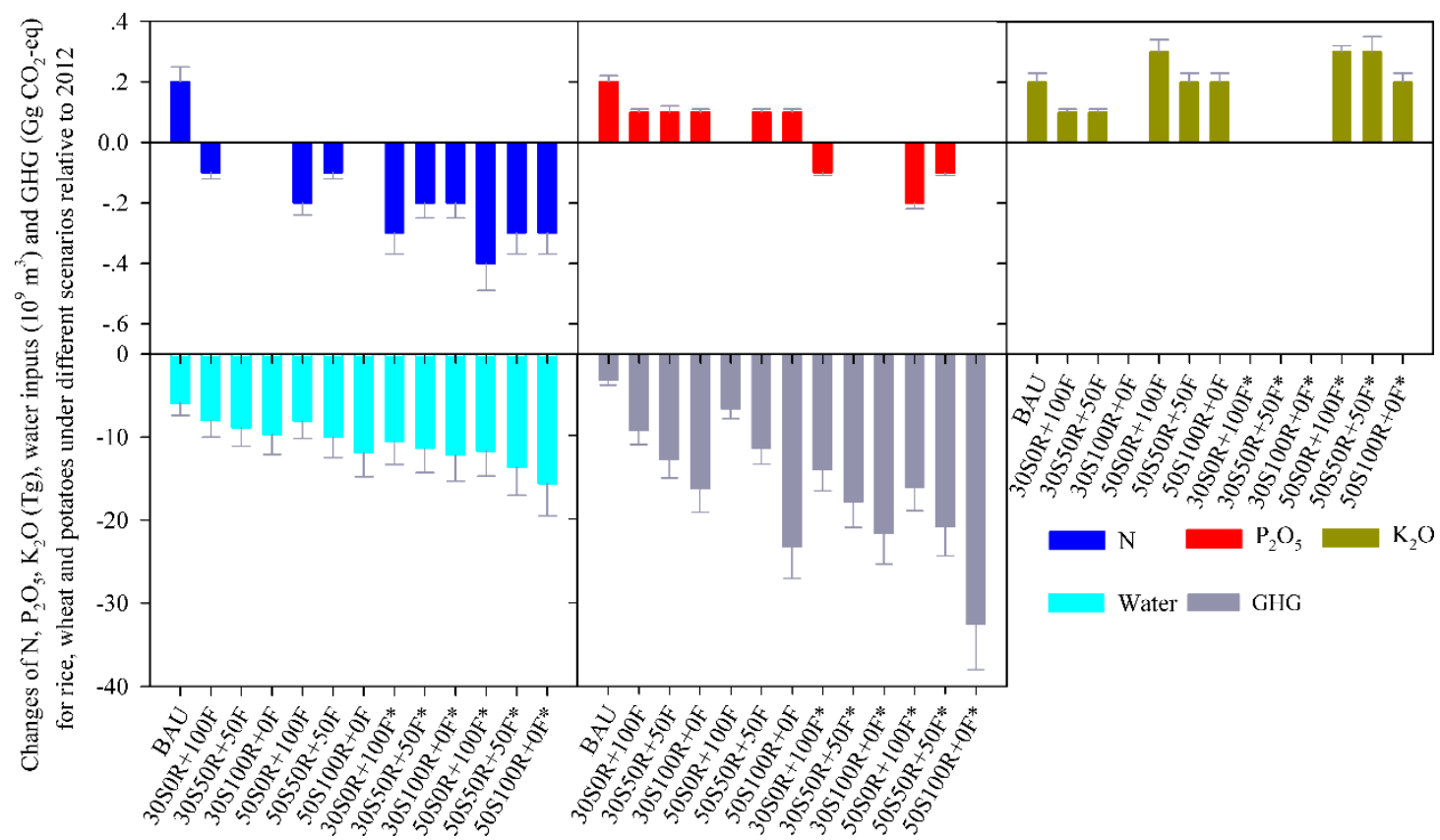

Figure 4. Chemical $\mathrm{N}-, \mathrm{P}_{2} \mathrm{O}_{5}$ - and $\mathrm{K}_{2} \mathrm{O}$-feitilizer inputs, irrigation-water consumptions and total GHG for rice, wheat, conventionally grown potatoes (Potato-Con), and optimally grown potatoes (Potato-Opt) under different scenarios, compared with 2012.

\section{Discussions}

\subsection{Effect of PSF on Rice and Flour Consumption and Rice and Wheat Production}

The per capita total consumption of potatoes as a staple food and as a vegetable, in $30 \%$ and $50 \%$ of the PSF scenarios, would be $9.6 \pm 1.1$ and $13.5 \pm 1.4 \mathrm{~kg} \mathrm{yr}^{-1}$ in urban areas, and $15.7 \pm 1.8$ and $22.1 \pm 2.3 \mathrm{~kg} \mathrm{yr}^{-1}$ in rural areas, respectively, in 2020 (Table 2). Even these higher amounts, though, are lower than the world average annual per capita potatoes consumption of $20.8 \mathrm{~kg} \mathrm{yr}^{-1}$ (except for the $50 \%$ PSF scenario in rural areas), and far below the potato consumption per capita in 2005 in Europe $(96.1 \mathrm{~kg})$ and North America $(57.9 \mathrm{~kg})$ [4]. Asia as a whole, though, is an area with the fastest growth of potato consumption, and per capita potato consumption amounts were as large as $40-80 \mathrm{~kg} \mathrm{yr}^{-1}$ in some countries, such as Kazakhstan, Lebanon, Israel, etc. [33]. Hence China has a large potential for growth of potatoes as a staple food, and the Chinese government's goal will increase potatoes as a staple food amounts to $5.2 \pm 0.7$ and $12.2 \pm 1.7 \mathrm{Tg} \mathrm{yr}^{-1}$ under $30 \%$ and $50 \%$ of PSF targets. Such an increase can substitute for $3.1 \%$ and $7.5 \%$ of the total rice and flour consumption in 2020, would reduce flour consumption by $5.2 \pm 0.7$ and $12.2 \pm 1.7 \mathrm{Tg} \mathrm{yr}^{-1}$ under the $30 \mathrm{~S}_{0 \mathrm{R}+100 \mathrm{~F}}$ and $50 \mathrm{~S}_{0 \mathrm{R}+100 \mathrm{~F}}$ scenarios; or reduce rice consumption by almost identical amounts under the $30 \mathrm{~S}_{100 \mathrm{R}+0 \mathrm{~F}}$ and $50 \mathrm{~S}_{100 \mathrm{R}+0 \mathrm{~F}}$ scenarios; or decrease rice and flour consumption amounts by $2.6 \pm 0.4$ and $6.1 \pm 0.9 \mathrm{Tg} \mathrm{yr}^{-1}$, respectively, under the $30 \mathrm{~S}_{50 \mathrm{R}+50 \mathrm{~F}}$ and $50 \mathrm{~S}_{50 \mathrm{R}+50 \mathrm{~F}}$ scenarios.

The ratios of grain supplies for the different types of flour in China are about $78.0 \%$, and about $3.0 \%$ of grains are lost during processing [34]. Under the scenarios where potatoes are completely substituted for flour as a staple food $\left(30 \mathrm{~S}_{0 \mathrm{R}+100 \mathrm{~F}}, 50 \mathrm{~S}_{0 \mathrm{R}+100 \mathrm{~F}}\right)$, and those where potatoes are substituted for half the flour $\left(30 \mathrm{~S}_{50 \mathrm{R}+50 \mathrm{~F}}, 50 \mathrm{~S}_{50 \mathrm{R}+50 \mathrm{~F}}\right), 8.5 \pm 1.5,19.8 \pm 3.6,4.2 \pm 0.8$ and $9.9 \pm 1.8 \mathrm{Tg}$ wheat $\mathrm{yr}^{-1}$ or $7.0 \%, 16.2 \%, 3.5 \%$ and $8.1 \%$ of the total wheat demand $\left(121.9 \pm 23.6 \mathrm{Tg} \mathrm{yr}^{-1}\right)$ under the BAU scenario will be substituted, respectively, in 2020 . The edible portion of rice is $70.5 \%$, and about $3.0 \%$ of rice is lost in processing [34]. Under the scenarios where potatoes are completely substituted for rice as a staple food $\left(30 \mathrm{~S}_{100 \mathrm{R}+0 \mathrm{~F}}, 50 \mathrm{~S}_{100 \mathrm{R}+0 \mathrm{~F}}\right)$ and those where potatoes are substituted for half the rice as a staple food $\left(30 \mathrm{~S}_{50 \mathrm{R}+50 \mathrm{~F}}, 50 \mathrm{~S}_{50 \mathrm{R}+50 \mathrm{~F}}\right), 10.1 \pm 1.8,23.7 \pm 4.3,5.1 \pm 0.9$ and $11.8 \pm 2.1 \mathrm{Tg} \mathrm{yr}^{-1}$ or $5.2 \%, 12.2 \%, 2.6 \%$ 
and $6.1 \%$ of the total rice demand $\left(194.6 \pm 37.8 \mathrm{Tg} \mathrm{yr}^{-1}\right)$ under the BAU scenario will be substituted in 2020 .

With population and economic growth, the demand for grain in China is expected to reach $218 \mathrm{Tg}$ for rice and $125 \mathrm{Tg}$ for wheat by 2030, compared to the 204 and $114 \mathrm{Tg}$ of rice and wheat demands in 2012 [7]. The results of the current study indicate that the demands for rice for staple-food consumption will fall to about $195 \pm 38 \mathrm{Tg}$ by 2020 , because of the decline in per capita rice consumption, especially in urban resident's diets (Figure 1). Indeed, the rice reduction has already exceeded the expected increase in rice demand from population growth [22]. But the demand for winter wheat is expected to reach $122 \pm 24 \mathrm{Tg}$ by 2020 , according to a trend found in a previous study, because per capita flour consumption has been relatively stable in recent decades, keeping pace with population growth. However, Chinese agriculture is restricted by limited arable land, declining water availability, increasing costs for rural labor, and increasing vulnerability to climate change [35], resulting in difficulty in increasing cereal production. The increased demand for wheat will be only relying on improving yields. It was indicated that, using the same planting area as in 2012, the total production of wheat would reach $174 \mathrm{Tg}$ by 2030 if wheat grain yields of farmers could reach to $80 \%$ of the attainable yield level through integrated soil-crop management systems [7].

PSF could reduce the grain demand for rice and/or winter wheat under the different substitution scenarios. For example, under the $30 \mathrm{~S}_{50 \mathrm{R}+50 \mathrm{~F}}, 30 \mathrm{~S}_{0 \mathrm{R}+100 \mathrm{~F}}, 50 \mathrm{~S}_{50 \mathrm{R}+50 \mathrm{~F}}$ and $50 \mathrm{~S}_{0 \mathrm{R}+100 \mathrm{~F}}$ scenarios, the demands for rice could be expected to reach only $190 \pm 36,185 \pm 34,183 \pm 31$ and $171 \pm 31 \mathrm{Tg}$-lower by $2.6 \%, 5.1 \%, 6.0 \%$ and $12.1 \%$ than that under the BAU scenario, by 2020 . Under the scenarios of $30 \mathrm{~S}_{0 \mathrm{R}+100 \mathrm{~F}}, 30 \mathrm{~S}_{50 \mathrm{R}+50 \mathrm{~F}}, 50 \mathrm{~S}_{0 \mathrm{R}+100 \mathrm{~F}}$ and $50 \mathrm{~S}_{50 \mathrm{R}+50 \mathrm{~F}}$, the demands for wheat could be expected to reach only $113 \pm 21,118 \pm 22,102 \pm 18$ and $112 \pm 20 \mathrm{Tg}$-all lower than that under the BAU scenario, by 2020, close to the actual demand in 2012. These results imply that if China could achieve the targets of $30-50 \%$ PSF consumption, the wheat production likely would meet the demand placed on it by population growth by 2020, under current yields and arable land availability across China. Additionally, the planting area required for wheat production could be reduced by $28 \%$ relative to wheat planting area in 2012 , if farmers could achieve wheat grain yields of $80 \%$ of the yield level attainable through integrated soil-crop management systems [7,36].

\subsection{Effect of PSF on Chemical $\mathrm{N}-, \mathrm{P}_{2} \mathrm{O}_{5}$ - and $\mathrm{K}_{2} \mathrm{O}$-fertilizer Application on Rice, Wheat and Potato Systems}

Different substitute amounts of potatoes for rice and wheat, integrated with the use efficiencies of chemical $\mathrm{N}-, \mathrm{P}_{2} \mathrm{O}_{5}$ - and $\mathrm{K}_{2} \mathrm{O}$-fertilizer and irrigation-water in different cropping systems, will generate certain effects on total chemical N-, $\mathrm{P}_{2} \mathrm{O}_{5^{-}}, \mathrm{K}_{2} \mathrm{O}$-fertilizer and irrigation-water consumption for these crop systems (Figure 4): N application on the three crops would fall slightly, by $0.2 \pm 0.1-0.4 \pm 0.1 \mathrm{Tg} \mathrm{yr}^{-1}$ relative to the BAU, and we found that the more the amount of wheat substituted by potatoes, the more the $\mathrm{N}$ would be reduced, because the $\mathrm{PFP}_{\mathrm{N}}$ for potatoes is higher than that for wheat ( $35.8 \mathrm{vs}$. $28.2 \mathrm{~kg} \mathrm{~kg}^{-1} \mathrm{~N}$ ). Substituting potatoes for rice has the opposite effect: The $\mathrm{P}_{2} \mathrm{O}_{5}$ amounts for the three crops would be slightly reduced, by $0.1 \pm 0.01-0.2 \pm 0.02 \mathrm{Tg} \mathrm{yr}^{-1}$, the more potatoes that are substituted for rice, the less $\mathrm{P}_{2} \mathrm{O}_{5}$ can be decreased relative to the $\mathrm{BAU}$, because the $\mathrm{PFP}_{\mathrm{P} 2 \mathrm{O} 5}$ for rice is higher than that for potatoes ( 98.8 vs. $57.3 \mathrm{~kg} \mathrm{~kg}^{-1} \mathrm{P}_{2} \mathrm{O}_{5}$ ). $\mathrm{K}_{2} \mathrm{O}$ application on three crops would decrease slightly, by $0.1 \pm 0.02-0.2 \pm 0.03 \mathrm{Tg} \mathrm{yr}^{-1}$ in three $30 \%$ PSF scenarios relative to the BAU, but showed a slight increase in three $50 \%$ PSF scenarios, because the lower $\mathrm{PFP}_{\mathrm{K} 2 \mathrm{O}}$ for potatoes than that for rice and wheat ( 39.3 vs. 68.7 and $81.3 \mathrm{~kg} \mathrm{~kg}^{-1} \mathrm{~K}_{2} \mathrm{O}$ ). China's conventional potato yield is higher than the world average by about $25.4 \%$, however, a relative large potential for improving potato yields by $25.6 \%$ (up to $32.4 \mathrm{t} \mathrm{ha}^{-1}$ ) through optimizing management practices. The optimized potato yield is only about $70 \%$ of that in the USA, Germany, France and the Netherlands, even though China is among the top 10 countries for potato output (Figure S4) [2]. If the potato yield could be improved to the optimized level, further more reductions of $\mathrm{N}, \mathrm{P}_{2} \mathrm{O}_{5}$ and $\mathrm{K}_{2} \mathrm{O}$ could be achieved, relative to the $\mathrm{BAU}$, under all the substitution scenarios, except for $\mathrm{K}_{2} \mathrm{O}$ in three $50 \%$ PSF scenarios. 
In the past decade, the mean increase rates of chemical $\mathrm{N}-, \mathrm{P}_{2} \mathrm{O}_{5}-$ and $\mathrm{K}_{2} \mathrm{O}$-fertilizer application were $0.49,0.43$ and $0.41 \mathrm{Tg} \mathrm{yr}^{-1}$, respectively [17]. About $34.5 \%$ of the $\mathrm{N}, 32.4 \%$ of the $\mathrm{P}_{2} \mathrm{O}_{5}$ and $34.6 \%$ of the $\mathrm{K}_{2} \mathrm{O}$ were consumed by rice, wheat and tuber production in China [37]. The chemical $\mathrm{N}_{2} \mathrm{P}_{2} \mathrm{O}_{5}$ and $\mathrm{K}_{2} \mathrm{O}$ applications on rice, wheat and potatoes will slightly increase under the BAU scenario. However, chemical N-, $\mathrm{P}_{2} \mathrm{O}_{5}$ - and $\mathrm{K}_{2} \mathrm{O}$-fertilizer inputs to rice, wheat and potatoes showed different levels of reduction in all of the substitution scenarios except for $\mathrm{K}_{2} \mathrm{O}$ under three $50 \%$ PSF scenarios, relative to BAU. The latest statistics suggested that the agricultural fertilizer use decreased by $0.4 \mathrm{Tg}$ in 2016 compared to 2015 [17]. This is the first negative growth since the 1970s and achieves the national goal of zero growth in fertilizer use three years in advance [30], which is attributed to the long-term effort to implement the soil testing and fertilizer recommendation technology from 2005, and the increase in crop yield and the ratios of straw return to field in majority of provinces [36,38], and the increase in manure caused by increases in livestock and poultry production [39]. Substituting rice and flour with PSF will lead to additional decrease in chemical N-, $\mathrm{P}_{2} \mathrm{O}_{5}$ - and $\mathrm{K}_{2} \mathrm{O}$-fertilizer inputs for the increasing food production in China from a long-term perspective.

\subsection{Effect of PSF on Irrigation-Water Use and Total GHG for Rice, Wheat and Potatoes, and for Rice and Wheat Production}

PSF can also decrease irrigation-water use for three crops, and we found that the greater amount of potatoes substituted for rice, the greater amount of irrigation-water would be reduced (Figure 4), because rice has a low IWUE relative to potatoes and wheat (Table S1). The saved irrigation-water compared to 2012 by substituting rice and flour in varying proportions of potatoes, as a staple food, is equal to the total water use of approximately $17.9 \pm 4.9,20.0 \pm 5.4$ and $21.8 \pm 5.9$ million people (based on per capita use of $445 \mathrm{~m}^{3}$ ) in 2015 [31], in the $30 \%$ of PSF scenarios. Under the $50 \%$ of PSF scenarios, these amounts come to the total water use of approximately $18.2 \pm 4.9,22.5 \pm 6.0$ and $26.7 \pm 7.1$ million people in 2015. These reductions could alleviate the shortage of freshwater resources in China. If potato yields could be improved to the optimized level, even more irrigation-water could be saved, under all the substitution scenarios. The largest reduction in irrigation-water was found for the $50 S_{100 \mathrm{R}+0 \mathrm{~F}}$ scenario, equal to the total water use of about $35.1 \pm 7.1$ million people in 2015 .

Wheat yield would be reduced by $8.5 \pm 1.5,4.2 \pm 0.8,19.8 \pm 3.6$ and $9.9 \pm 1.8 \mathrm{Tg}$ under the $30 \mathrm{~S}_{0 \mathrm{R}+100 \mathrm{~F}}, 30 \mathrm{~S}_{50 \mathrm{R}+50 \mathrm{~F}}, 50 \mathrm{~S}_{0 \mathrm{R}+100 \mathrm{~F}}$ and $50 \mathrm{~S}_{50 \mathrm{R}+50 \mathrm{~F}}$ scenarios, relative to the BAU, by 2020 . These amounts are equal to about $1.3 \pm 0.4,0.7 \pm 0.2,3.0 \pm 0.9$ and $1.5 \pm 0.4$ million ha for winter wheat in the NCP, based on a yield of $6.6 \mathrm{Mg} \mathrm{ha}^{-1}$ of winter wheat in the NCP in 2012, accounting for $11.4 \%, 6.1 \%$, $26.3 \%$ and $13.2 \%$ of the total winter wheat sown (11.4 million ha) in the NCP [27]. The possible region for cutting winter wheat by recommending PSF locate at NCP-I in Figure S1, where it is facing a rapid depletion of groundwater due to excessive irrigation for winter wheat $[28,40]$. Some recent studies have been carried out, on the possibility of saving irrigation water by converting to a winter wheat-summer maize-spring maize crops system, over a two-year period, rather than the typical winter wheat-summer maize double-cropping system, in the NCP [41,42]. The decrease in winter wheat production could extend the spring maize-summer maize double cropping system in the NCP, which in turn could decrease irrigation water by $28.0-62.7 \%$, while increasing maize yield by $43.7-58.6 \%$ compared to the conventional winter wheat-summer maize double-cropping system [43,44]. This change fits in well with the trend of increasing the amount of maize for animal feed, as the demand for animal protein increases and staple foods such as wheat are decreasing in the human diet as economic development proceeds [22]. If potatoes can substitute for winter wheat, irrigation water requirements would decrease from $182 \mathrm{~mm}$ to $97 \mathrm{~mm}$, and adding in the mean annual $70 \mathrm{~mm}$ irrigation for summer maize [42] would reduce the irrigation water requirement from $252 \mathrm{~mm}$ for the winter wheat-summer maize double cropping system to $167 \mathrm{~mm}$ for the potatoes and maize double cropping system. It has been found that groundwater exploitation should be controlled to below $150 \mathrm{~mm} \mathrm{yr}^{-1}$ to slow the declining in groundwater table in the NCP [45]. Sowing potatoes therefore has a larger potential for mitigating the drop in the groundwater table than does sowing wheat, and it might be a good adaption 
to future climate change, with its expected significant warming trend and lower precipitation amounts in the NCP [46].

Rice yield would be reduced by $5.1 \pm 0.9,10.1 \pm 1.8,11.8 \pm 2.1$ and $23.7 \pm 4.3 \mathrm{Tg} \mathrm{yr}^{-1}$ under the $30 \mathrm{~S}_{50 \mathrm{R}+50 \mathrm{~F}}, 30 \mathrm{~S}_{100 \mathrm{R}+0 \mathrm{~F}}, 50 \mathrm{~S}_{50 \mathrm{R}+50 \mathrm{~F}}$ and $50 \mathrm{~S}_{100 \mathrm{R}+0 \mathrm{~F}}$ scenarios, relative to the BAU, if the aim of potatoes as staple food policy achieved. These amounts are equal to about $0.7 \pm 0.1,1.4 \pm 0.4,1.7 \pm 0.3$ and $3.3 \pm 0.9$ million ha for early rice, based on a yield of $7.1 \pm 1.3 \mathrm{Mg} \mathrm{ha}^{-1}$ of early rice, accounting for $12.1 \%, 24.1 \%, 29.3 \%$ and $56.9 \%$ of the total early rice sown (5.8 million ha) in China in 2012 [17]. It is predicted that the proportion of total water consumption used by agriculture would decrease to $50 \%$ by 2020 , from the current $65 \%$ in some parts of Asia [47]. The water consumed by rice production accounts for $45 \%$ of total freshwater consumption in Asia [48], an amount that threatens continued high rice production in China. Switching to PSF could also decrease the early rice sown area by $12.1-56.9 \%$, based on conventional levels of yield, by substituting different proportions of rice with potatoes. Hence, PSF have a large potential for mitigating the pressure on China's rice production under the limited freshwater resources, ensuring China's food security under future climate change.

Total GHG emission for rice, wheat and potatoes would be decreased by $3.4 \pm 0.6 \mathrm{Gg} \mathrm{CO}_{2}$-eq yr ${ }^{-1}$ because the large reduction of GHG for rice in the BAU scenario. More $6.0 \pm 0.8-13.0 \pm 1.9$ and $3.4 \pm 0.4-19.9 \pm 2.9 \mathrm{Tg} \mathrm{CO}_{2}$-eq $\mathrm{yr}^{-1}$ could reduce compared to $\mathrm{BAU}$ in $30 \%$ and $50 \%$ of $\mathrm{PSF}$ scenarios, respectively. The reductions of total GHG, equal to $1.1-9.0 \%$ of total $\mathrm{CO}_{2}$-eq emissions (319 $\mathrm{Tg}$ ) associate with $\mathrm{CH}_{4}$ and $\mathrm{N}_{2} \mathrm{O}$ emitted from Chinese agroecosystems in 2005 [49]. Although net GHG of potatoes $\left(3323 \pm 1037-3636 \pm 1140 \mathrm{~kg} \mathrm{CO}_{2}\right.$-eq ha $\left.{ }^{-1}\right)$ were significantly lower than that of rice and wheat in China (Figure 3), these values were significantly higher than that of $993-2350 \mathrm{~kg} \mathrm{CO}_{2}$-eq ha ${ }^{-1}$ for potatoes in Iran and Portugal [50,51], which were caused by the higher $\mathrm{CO}_{2}$-eq emissions from $\mathrm{N}$ input and power use for irrigation in China. It was implied that China has a large potential to reduce total GHG emissions for staple food production by further reducing net GHG in potato production.

\subsection{Effect of PSF on Potato Planting Under Different Scenarios}

Total potato consumption would reach $17.4 \pm 1.2$ and $24.4 \pm 2.0 \mathrm{Tg} \mathrm{yr}^{-1}$ in $30 \%$ and $50 \%$ PSF scenarios, respectively, in 2020. Under the yield level in $2012\left(25.8 \pm 7.9 \mathrm{Mg} \mathrm{ha}^{-1}\right)$, the sowing area of potatoes were expected to reach $6.8 \pm 2.2$ and $9.5 \pm 2.6$ million ha in $30 \%$ and $50 \%$ PSF scenarios, which is close to our government's target of increasing sown area of potatoes to 6.7 million ha by 2020 from 5.5 million ha in 2012, to achieve 30\% of the PSF. To achieve the goal of 50\% PSF, the planting area needs up to 10.0 million ha, while improving potato yields to more than $30 \mathrm{Mg} \mathrm{ha}^{-1}$, and no competition of land with rice, wheat or maize [52]. China has about 16.0 million ha of winter fallow cropland after late rice harvest in South China, and at least a quarter of this land can be used for planting potatoes, allowing a production of more than 60 million tons of food, enough to meet the food demand for 100 million people for 300 days [53]. In addition, $1.3 \pm 0.4-3.3 \pm 0.9$ million ha for irrigated winter wheat in the NCP and/or early rice across China could be converted into potatoes, under $30-50 \%$ of PSF scenarios. Winter fallow cropland plus the potential substituted wheat and early rice by potatoes area was high to about 5.3-7.3 million ha, which is adequate for the additional demand of 1.2-4.5 million ha potatoes in China, while the average potato yield can be improved to 32.4 $\mathrm{Mg} \mathrm{ha}^{-1}$ under optimized management practices (Table S5). Adopting PSF could decrease the planting of rice and wheat, and using winter fallow land for potato production could ameliorate the shortage of arable land. Increasing the share of PSF may be an effective measure for mitigating the increasing pressure on producing more cereal grain production on limited arable land induced by rapidly urbanization $[8,35]$, to ensure Chinese food security.

\subsection{Effect of PSF on Food Energy and Nutrient Supply}

The substitution of rice and flour with the same amount of potatoes will reduce the supply of plant food protein supply because of lower $\mathrm{N}$ content in potatoes than that in rice and flour [18,22]. However, this substitution has no significant effect on the total supply of plant food $\mathrm{N}$, because only 
$3.1-7.5 \%$ of the total rice and flour consumption would be substituted by potatoes under different scenarios. According to data from China Food Composition, the per capita consumption of $141 \mathrm{~g}$ wheat flour, $150 \mathrm{~g}$ rice and $70 \mathrm{~g}$ rice flour per day together provide $63.1 \%, 53.5 \%$ and $92.6 \%$ of the recommended requirement of energy, macroelements and carbohydrates, respectively [54]; however, for many essential micronutrients, they provide about three-quarters to less than half of human bodily needs, and they provide none vitamins $A$ and $C$ [3]. The data from the national nutrition health survey results also showed that the Chinese overweight and obesity rates increased by $7.3 \%$ and $4.8 \%$ in 2010-2012 compared to 2002, and that there is still a deficiency of Ca, iron, vitamin A and vitamin D, and that the prevalence of chronic diseases such as hypertension and diabetes is growing rapidly and spreading to a younger group [16]. These alarming changes may have a close correlation with Chinese residents' unhealthful staple-food consumption and nutrition structure. Potatoes, containing a variety of nutrients essential to the human body, include higher lysine content than wheat or rice. Furthermore, potatoes' amino acid composition is close to that of easily absorbed soy protein, and they contain carotenoids not found in rice or wheat [54]. The potato flour can also make a significant contribution to the dietary intake of certain minerals including $\mathrm{K}, \mathrm{P}, \mathrm{Mg}$ and iron, as well as of dietary fibers, vitamin C and phenolic compounds [55], while delivering only modest amounts of saturated fatty acid and sodium [56]. If a resident who consumes $250 \mathrm{~g}$ of steamed bread per day as a staple food substituted $35 \%$ potato steamed bread for wheat-flour steamed bread, he could take $88.8 \%$ and $119.5 \%$ of the human daily requirement for vitamin $C$ and $K$, far above the $19.6 \%$ and $42.8 \%$ of the daily vitamin $\mathrm{C}$ and $\mathrm{K}$ requirements from the same amount of ordinary steamed bread; and in addition, the total crude fat intake by a human body from potato steamed bread is lower than from ordinary steamed bread by about 21.8\% [3] (Table S10). Moreover, the total nutrient supply index of this study increased by $63.0 \%$-from 0.27 for $100 \%$ wheat bread $(250 \mathrm{~g}$ ) to 0.44 for $35 \%$ potato bread ( $250 \mathrm{~g}$; Table S10), which represent potatoes as part of staple foods could supply more profitable nutrients than ordinary steamed bread. It was indicated that potatoes could increase the nutrient density of the diet by providing a relatively high micronutrient contribution, compared with energy content [56]. Our results also showed that the energy supply only $0.4-1.6 \%$ difference between potato substitution for rice and flour scenarios and only rice and flour scenario in 2012 (Table S9). In other words, despite being from the same energy perspective of potato substitution for rice and flour, it will not significantly affect our results and conclusions. These suggest that PSF might improve the overall health of the Chinese people by improving dietary nutrition. However, the price of potato steamed bread is about double that of ordinary steamed bread in supermarkets [57]. The high price may result in the consumers unwilling to buy potatoes products. The Chinese government should not only support the development of advanced potato processing technologies and help increase the capacities of processing enterprises, but also subsidize processing enterprises to reduce the costs of potato based products [57], and to minimize the price gap between wheat-flour-only and potato-plus-wheat-flour products.

\subsection{The Limitations and Future Research}

We did a comprehensive environmental assessment of potato as staple food policy in China, focusing on the environmental benefits of substituting rice and wheat by potato. There are some limitations that the extrapolation of per capita habitual staple-food intake for 2013-2020 based on the historical trends from 2002 to 2012, using a simply common trend projection method [23], the possible effect of economic development on staple-food consumption should be considered in future research, and we predicted the amounts of potatoes consumed as a vegetable in urban and rural populations in 2020 by historical trends of tuber consumption from 2002 to 2012, and assuming that the proportion of potatoes to other tubers keep constant as reported in 2012 [5], because of no available data on the future condition. Moreover, we designed different proportions of potato substitutes for rice and flour and substituting potatoes for equal amounts of rice and/or flour, and we illustrated that this substitution had no significant effect on food energy supply from rice, flour plus potatoes in all substitution scenarios, future research can be tried to use equal amounts of the nutrition perspective to substitute for rice and 
flour with potatoes. The $\mathrm{N}, \mathrm{P}_{2} \mathrm{O}_{5}$ and $\mathrm{K}_{2} \mathrm{O}$ sourced from organic fertilizers were excluded in this study because of the reasons described in the data collection section, this part of $\mathrm{N}-, \mathrm{P}_{2} \mathrm{O}_{5}$ - and $\mathrm{K}_{2} \mathrm{O}$-fertilizers should be included in the comparison of $\mathrm{N}$ use efficiencies of three crops in future research. We did not consider the potential effect of PSF on the types and prices of staple foods. The price of potato steamed bread is about double that of ordinary steamed bread in supermarkets [57], because until now the price of potato granules is about triple the price of wheat flour because the processing industry is of a low capacity in China. The high price may result in the consumers unwilling to buy potatoes products. How to minimize the price gap between wheat-flour-only and potato-plus-wheat-flour or rice flour products is urgently needed for policy makers. Moreover, the implementation of PSF might generate certain effects on the inputs and outputs of potatoes, rice and wheat production, the price of associate food products, and cost of some economic input for establishing the corresponding processing industry and for promoting this policy, hence, the cost-benefit analysis of potato production to the rest of selected cropping systems in term of the environmental impact assessment, and the cost of $\mathrm{CO}_{2}$-eq emissions of the selected cropping systems compared to the potato system is urgently worth doing in future research.

\section{Conclusions}

In this study we studied the comprehensive effect of the government's target of having $30 \%$ of total consumed potatoes as a staple food in China, on chemical $\mathrm{N}-, \mathrm{P}_{2} \mathrm{O}_{5}$ - and $\mathrm{K}_{2} \mathrm{O}$-fertilizer, irrigation-water inputs and total GHG emissions for rice, wheat and potatoes and on energy supply and nutrition supplies, by substituting potatoes for equal amounts of rice and/or flour. The results showed that $30 \%$ of the consumed potatoes as a staple-food policy could decrease total chemical $\mathrm{N}$ fertilizer and irrigation water inputs, reduce total GHG emissions and mitigate $\mathrm{P}_{2} \mathrm{O}_{5}$ fertilizer inputs for three crops, relative to the 2012 and business as usual scenario, by reducing early rice across China, and/or winter wheat in the NCP. The decreases in irrigation water in different substitute scenarios compared to 2012 are equivalent to the water use of about $17.9 \pm 4.9-21.8 \pm 4.8$ million people in 2015. The reduction in winter wheat production in the NCP could convert $6.1-11.4 \%$ of the typical winter wheat-summer maize double cropping system to a potato-summer maize system and a winter wheat-summer maize-spring maize system, with three harvests every two years, to mitigate the decline of the groundwater table and a $12.1-24.1 \%$ of reduction in early rice sowing could mitigate the pressure on the increasing in rice demand anticipated by China's increasing population under limited freshwater resources in the future. More $\mathrm{N}$ - and $\mathrm{P}_{2} \mathrm{O}_{5}$-fertilizer, irrigation-water and total GHG could be reduced if the proportion of PSF rose to $50 \%$, coupled with improving potato yields. Our results implied that China can take the challenges of producing more grains anticipated by population and economic growth with fewer inputs, and with reduced environmental costs by making potatoes entered into staple diets, while ensuring an equal amount of energy supply and more healthful nutrition supplies. In addition, potato as a staple food policy might contribute to the adjustment of agricultural structure in some areas with serious water deficits under climate change, especially irrigated wheat on the NCP.

Supplementary Materials: The following are available online at http://www.mdpi.com/1660-4601/16/15/2700/s1, Table S1: $\mathrm{CO}_{2}$-eq emission from $\mathrm{N}_{2} \mathrm{O}$ and $\mathrm{CH}_{4}$ emissions, irrigation, fuel, pesticides, film and fertilizers input, Chemical N-, $\mathrm{P}_{2} \mathrm{O}_{5}$ - and $\mathrm{K}_{2} \mathrm{O}$ fertilizer and irrigation-water inputs for potatoes, wheat in the North China Plain $(\mathrm{NCP})$, and early rice, and yields of the three crops, and partial factor productivities of fertilizers $\mathrm{N}\left(\mathrm{PFP}_{\mathrm{N}}\right), \mathrm{P}_{2} \mathrm{O}_{5}$ $\left(\mathrm{PFP}_{\mathrm{P} 2 \mathrm{O} 5}\right), \mathrm{K}_{2} \mathrm{O}\left(\mathrm{PFP}_{\mathrm{K} 2 \mathrm{O}}\right)$ and irrigation water production efficiency (IWUE); Table $\mathrm{S} 2$ : $\mathrm{CO}_{2}$-eq emission from $\mathrm{N}_{2} \mathrm{O}$ and $\mathrm{CH}_{4}$ emissions, fertilizers input, power for irrigation, fuel in farm operations, pesticide application, and film in winter wheat across China except for wheat on the NCP, middle-season rice, and late rice production; Table S3: Irrigation-water intensity, plant area and average yield of early, middle-season and late rice in China; Table S4: Irrigation rate, power consumption, power used per unit of irrigation rate and electricity charges in the Chinese main crop systems in different regions; Table S5: $\mathrm{CO}_{2}$-eq emission from $\mathrm{N}_{2} \mathrm{O}$ and $\mathrm{CH}_{4}$ emissions, and chemical N-, $\mathrm{P}_{2} \mathrm{O}_{5}$ - and $\mathrm{K}_{2} \mathrm{O}$ fertilizer $\left(\mathrm{kg} \mathrm{CO}_{2}\right.$-eq ha $\left.{ }^{-1}\right)$, Chemical N-, $\mathrm{P}_{2} \mathrm{O}_{5}$ - and $\mathrm{K}_{2} \mathrm{O}$ fertilizer and irrigation-water application, yields of potatoes, partial factor productivity of fertilizer $\mathrm{N}\left(\mathrm{PFP}_{\mathrm{N}}\right), \mathrm{P}_{2} \mathrm{O}_{5}\left(\mathrm{PFP}_{\mathrm{P} 2 \mathrm{O} 5}\right)$ and $\mathrm{K}_{2} \mathrm{O}\left(\mathrm{PFP}_{\mathrm{K} 2 \mathrm{O}}\right)$, and irrigation-water production efficiency (IWUE) under optimized potato management practices in China; Table S6: Per capita habitual food intake in 1982, 1992, 2002 and 2012 (g cap. $^{-1}$ day $^{-1}$ ); Table S7: Proportions of kitchen waste composed of cereals, potatoes and beans; Table S8: Chemical N-, $\mathrm{P}_{2} \mathrm{O}_{5}-$ and $\mathrm{K}_{2} \mathrm{O}$-feitilizer inputs, irrigation-water 
consumptions and total GHG for rice, wheat, conventionally grown potatoes (Potato-Con), and optimally grown potatoes (Potato-Opt) under different scenarios in 2020, compared with BAU scenario (mean \pm sd); Table S9: Energy supply under the different substitution scenarios in 2020, in comparison with 2012; Table S10: Comparison of nutritional components between $35 \%$ potato bread and $100 \%$ wheat bread, and the nutrition of $35 \%$ potato bread (250 g) and 100\% wheat bread (250 g); Figure S1: Specific distributions of early rice, winter wheat and potato systems at county-level across China. NCP-I and NCP-R represent the irrigated- and rainfed-winter wheat in the NCP; Figure S2: Chemical N-, $\mathrm{P}_{2} \mathrm{O}_{5}$ - and $\mathrm{K}_{2} \mathrm{O}$-fertilizer and irrigation-water consumption and their use efficiencies for potatoes, wheat in the North China Plain, and early rice across China; Figure S3: Comparison of chemical N-, $\mathrm{P}_{2} \mathrm{O}_{5}$-and $\mathrm{K}_{2} \mathrm{O}$-fertilizer and irrigation-water consumption and their use efficiencies, between conventional (left) and optimized (right) potato management practices; Figure S4: Yields of potato in the top 10 potato-output countries, and average potato yields, worldwide. This information is available free of charge via the Internet at http://pubs.acs.org/.

Author Contributions: For research articles with several authors, a short paragraph specifying their individual contributions must be provided. The following statements should be used "conceptualization, B.G. and S.C.; methodology, B.G.; software, W.H.; validation, B.G., W.H. and Y.C.H.; formal analysis, B.G.; investigation, Y.F.H.; resources, S.D.; data curation, B.G., and L.W.; writing-original draft preparation, B.G.; writing-review and editing, S.H. and X.X.; visualization, L.W.; supervision, B.G.; project administration, S.C.; funding acquisition, S.C.", please turn to the CRediT taxonomy for the term explanation. Authorship must be limited to those who have contributed substantially to the work reported.

Funding: This research was funded by the Young Talents Projects of the Institute of Urban Environment, Chinese Academy of Sciences (IUEMS201402), the International (regional) cooperation and exchange programs, the National Natural Science Foundation of China (NSFC-JPI_UE, 7181101187), the National Natural Science Foundation of China (71704171), and the National Basic Research Program of China (2014CB953801).

Acknowledgments: This research was funded by the Young Talents Projects of the Institute of Urban Environment, Chinese Academy of Sciences (IUEMS201402), the International (regional) cooperation and exchange programs, the National Natural Science Foundation of China (NSFC-JPI_UE, 7181101187), the National Natural Science Foundation of China (71704171), and the National Basic Research Program of China (2014CB953801). And we would like to thank Prof. F.S. Zhang and Prof. Z.L. Cui for supplying detailed data on chemical $\mathrm{N}$ fertilizer application (mean $\pm \mathrm{sd}$ ) on rice and wheat in China, and thank all the authors of the literature we cited.

Conflicts of Interest: The authors declare no conflict of interest, and the funders had no role in the design of the study; in the collection, analyses, or interpretation of data; in the writing of the manuscript, or in the decision to publish the results.

\section{References}

1. MOA (Ministry of Agriculture of the people's republic of China). China Agricultural Statistics Yearbook; China Agriculture Press: Beijing, China, 2016.

2. FAO (Food and Agriculture Organization of the United Nations. Available online: http://www.fao.org/ faostat/zh/\#data/QC (accessed on 23 July 2019).

3. Sun, J.M.; Guo, Y.Z.; Miao, S.Q. Improvement of potatoes steamed bread to staple foods nutrition structure of Chinese resident. J. Agric. Sci. Technol. 2015, 17, 64-69, (in Chinese with English abstract).

4. Keijbets, M.J.H. Potato processing for the consumer: developments and future challenges. Potato Res. 2008, 51, 271-281. [CrossRef]

5. $\quad$ Fang, H.Y.; Guo, Q.Y.; Yu, D.M.; Wang, X.; Jia, F.M.; Xu, X.L.; Fang, Y.H.; Zhao, L.Y. Status of consumption of potato and its related products in Chinese residents from 2010 to 2012. J. Hygiene Res. 2016, 45, 538-541, (in Chinese with English Abstract).

6. Tang, J. Strategy implementation suggestion of promoting potato staple. Cross Cent. 2015, 3, 11. (In Chinese).

7. Chen, X.P.; Cui, Z.L.; Fan, M.S.; Vitousek, P.; Zhao, M.; Wang, Z.L.; Zhang, W.J.; Yan, X.Y.; Yang, J.C.; Deng, X.P.; et al. Producing more grain with lower environmental costs. Nature 2014, 514, 486-489. [CrossRef] [PubMed]

8. Burney, J.A.; Davis, S.J.; Lobell, D.B. Greenhouse gas mitigation by agricultural intensification. Proc. Natl. Acad. Sci. USA 2010, 107, 12052-12057. [CrossRef] [PubMed]

9. Perrone, D.; Hornberger, G. Frontiers of the food-energy-water trilemma: Sri Lanka as a microcosm of tradeoffs. Environ. Res. Lett. 2016, 11, 014005. [CrossRef]

10. Romero-Lankao, P.; McPhearson, T.; Davidson, D.J. The food-energy-water nexus and urban complexity. Nat. Clim. Chang. 2017, 7, 233-235. [CrossRef]

11. Behrens, P.; Kieftede, J.J.; Bosker, T.; Rodrigues, J.F.D.; de Koning, A.; Tukker, A. Evaluating the environmental impacts of dietary recommendations. Proc. Natl. Acad. Sci. USA 2017, 114, 13412. [CrossRef] 
12. Eshel, G.; Shepon, A.; Makov, T.; Milo, R. Land, irrigation water, greenhouse gas, and reactive nitrogen burdens of meat, eggs, and dairy production in the United States. Proc. Natl. Acad. Sci. USA 2014, 111, 11996-12001. [CrossRef]

13. Liu, Y.; Liu, L.Z.; Yu, X.H.; Zhang, D.; Dou, B.X. Effect of potato flour on the quality of wheat flour and noodle. Sci. Technol. Food Ind. 2016, 37, 163-167, (in Chinese with English abstract).

14. Kong, L.; Zhu, L.Z. Study on the advantages of carbon emissions in potato production based on agricultural inputs and LMDI model analysis. J. Agrotech. Ecol. 2016, 7, 111-121. (in Chinese).

15. Zhai, F.Y.; He, Y.N.; Ma, G.S.; Li, J.P.; Wang, Z.H.; Hu, Y.S.; Zhao, L.Y.; Cui, Z.H.; Li, Y.; Yang, X.G. Study on the current status and trend of food consumption among Chinese population. Chin. J. Epidemiol. 2005, 26, 485-488, (in Chinese with English abstract).

16. NHFPC (National Health and Family Planning Commission). Chinese Residents Dietary Nutrition and Chronic Disease Status Reports.; People's Medical Publishing House: Beijing, China, 2015.

17. NBSC (National Bureau of Statistics of China). China Statistical Yearbook; China Statistics Press: Beijing, China, 2017.

18. Ma, L.; Velthof, G.L.; Qin, W.; Zhang, W.F.; Liu, Z.; Zhang, Y.; Wei, J.; Lesschen, J.P.; Ma, W.Q.; Oenema, O.; et al. Nitrogen and phosphorus use efficiencies and losses in the food chain in China at regional scales in 1980 and 2005. Sci. Total Environ. 2012, 434, 51-61. [CrossRef]

19. Gao, B.; Huang, W.; Wang, L.; Huang, Y.F.; Ding, S.P.; Cui, S.H. Driving forces of nitrogen flows and nitrogen use efficiency of food systems in seven Chinese cities, 1990 to 2015. Sci. Total Environ. 2019, 676, 144-154. [CrossRef] [PubMed]

20. Mosier, A.R.; Halvorson, A.D.; Reule, C.A.; Liu, X.J. Net global warming potential and greenhouse gas intensity in irrigated cropping systems in Northeastern Colorado. J. Environ. Qual. 2006, 35, 1584-1598. [CrossRef]

21. Grassini, P.; Cassman, K.G. High-yield maize with large net energy yield and small global warming intensity. Proc. Natl. Acad. Sci. USA 2012, 109, 1074-1079. [CrossRef] [PubMed]

22. Gao, B.; Huang, Y.F.; Huang, W.; Shi, Y.L.; Bai, X.M.; Cui, S.H. Driving forces and impacts of food system nitrogen flows in China, 1990 to 2012. Sci. Total Environ. 2018, 610-611, 430-441. [CrossRef]

23. Li, Z.M. Study on the Development of Food Consumption and Nutrition between Urban and Rural Residents in China. Ph.D. Thesis, Chinese Academic of Agricultural Sciences, Beijing, China, 2007. (in Chinese with English abstract).

24. Wang, L.; Yang, Y.Z.; Feng, Z.M.; You, Z. Prediction of China's population in 2020 and 2030 on county scale. Geographical Res. 2014, 33, 310-322, (in Chinese with English abstract).

25. Bai, X.M.; Shi, P.J.; Liu, Y.S. Society: Realizing China's urban dream. Nature 2014, 509, 158-160. [CrossRef]

26. Wu, B.F.; Yuan, Q.Z.; Yan, C.Z.; Wang, Z.M.; Yu, X.F.; Li, A.M.; Ma, R.H.; Huang, J.L.; Chen, J.S.; Chang, C.; et al. Land cover changes of China from 2000 to 2010. Qua. Sci. 2014, 34, 723-731, (in Chinese with English abstract).

27. Liu, B.H.; Wu, L.; Chen, X.P.; Meng, Q.F. Quantifying the potential yield and yield gap of Chinese wheat production. Agron. J. 2016, 108, 1-7. [CrossRef]

28. Foster, S.; Garduño, H. China: Towards Sustainable Groundwater Resource Use for Irrigated Agriculture on the North. China Plain. Counterpart Organizations: Ministry of Water Resources (MWR), Institute of Water Resources and Hydropower (IWRH) and Guantao County Water Resources Bureau (GCWRB), the World Bank water resources website (wwww.worldbank.org/gwmate) and the Global Water Partnership website (www.gwpforum.org); The World Bank: Washington, DC, USA, 2004; pp. 1-16.

29. Wang, E.L.; Yu, Q.; Wu, D.R.; Xia, J. Climate, agricultural production and hydrological balance in the North China Plain. Int. J. Climatol. 2008, 28, 1959-1970. [CrossRef]

30. Gu, B.J.; Ju, X.T.; Chang, J.; Ge, Y.; Vitousek, P.M. Integrated reactive nitrogen budgets and future trends in China. Proc. Natl.Acad. Sci. USA 2015, 112, 8792. [CrossRef] [PubMed]

31. MWR (the Ministry of Water Resources of the People's Republic of China). China Water Resources Bulletin; MWR: Beijing, China, 2015.

32. IPCC. Good Practice Guidance and Uncertainty Management in National Greenhouse Gas; Inventories; IGES: Kanagawa, Japan, 2001.

33. Liu, Y.; Gao, M.J.; Luo, Q.Y.; Zhang, Q.; He, W.M. Analysis on the basis situation and characteristics of world potatoes consumption. World Agric. 2014, 5, 119-125, (in Chinese with English abstract). 
34. Ma, W.Q.; Li, J.H.; Wang, F.H.; Sisák, I.; Cushman, G.; Zhang, F.S. Nitrogen flow and use efficiency in production and utilization of wheat, rice, and maize in China. Agric. Syst. 2009, 99, 53-63. [CrossRef]

35. Fan, M.S.; Shen, J.B.; Yuan, L.X.; Jiang, R.F.; Chen, X.P.; Davies, W.J.; Zhang, F.S. Improving crop productivity and resource use efficiency to ensure food security and environmental quality in China. J. Exp. Bot. 2012, 63, 13-24. [CrossRef] [PubMed]

36. Zhang, W.F.; Cao, G.X.; Li, X.L.; Zhang, H.Y.; Wang, C.; Liu, Q.Q.; Chen, X.P.; Cui, Z.L.; Shen, J.B.; Jiang, R.F.; et al. Closing yield gaps in China by empowering smallholder farmers. Nature 2016, 537, 671. [CrossRef]

37. Heffer, P. Assessment of Fertilizer Use by Crop at the Global Level; International Fertilizer Industry Association: Paris, France, 2009.

38. Zhao, Y.C.; Wang, M.Y.; Hu, S.J.; Zhang, X.D.; Zhu, Q.Y.; Zhang, G.L.; Huang, B.; Zhao, S.W.; Wu, J.S.; Xie, D.T.; et al. Economics- and policy-driven organic carbon input enhancement dominates soil organic carbon accumulation in Chinese croplands. Proc. Natl. Acad. Sci. USA 2018, 115, 4045-4050. [CrossRef]

39. Bai, Z.H.; Ma, W.Q.; Ma, L.; Velthof, G.L.; Wei, Z.B.; Havlík, P.; Oenema, O.; Lee, M.R.F.; Zhang, F.S. China's livestock transition: Driving forces, impacts, and consequences. Sci. Adv. 2018, 4, eaar8534. [CrossRef]

40. Yang, X.L.; Chen, Y.Q.; Pacenka, S.; Gao, W.S.; Ma, L.; Wang, G.Y.; Yan, P.; Sui, P.; Steenhuis, S.T. Effect of diversified crop rotations on groundwater levels and crop water productivity in the North China Plain. J. Hydrol. 2015, 522, 428-438. [CrossRef]

41. Meng, Q.F.; Sun, Q.P.; Chen, X.P.; Cui, Z.L.; Yue, S.C.; Zhang, F.S.; Römheld, V. Alternative cropping systems for sustainable water and nitrogen use in the North China Plain. Agric. Ecosyst. Environ. 2012, 146, $93-102$. [CrossRef]

42. Gao, B.; Ju, X.T.; Meng, Q.F.; Cui, Z.L.; Christie, P.; Chen, X.P.; Zhang, F.S. The impact of alternative cropping systems on global warming potential, grain yield and groundwater use. Agric. Ecosyst. Environ. 2015, 203, 46-54. [CrossRef]

43. Wu, D. A Systematic Study on Adaptability of Maize-Maize Double Cropping in the Hebei Plain. Master's Thesis, Hebei Agricultural University, Baoding, China, 2014.

44. Zhou, W.L. Evaluation of nutrients and water use efficiency of different maize wheat cropping systems in the North China Plain. Ph.D. Thesis, China Agricultural University, Beijing, China, 2016.

45. Chen, J.Y.; Tang, C.Y.; Shen, Y.J.; Sakura, Y.; Kondoh, A.; Shimada, J. Use of water balance calculation and tritium to examine the dropdown of groundwater table in the piedmont of the North China Plain. Environ. Geol. 2003, 44, 564-571. [CrossRef]

46. Liu, Y.; Wang, E.L.; Yang, X.G.; Wang, J. Contributions of climatic and crop varietal changes to crop production in the North China Plain, since 1980s. Glob. Chang. Biol. 2010, 16, 2287-2299. [CrossRef]

47. Jiang, Y. China's water scarcity. J. Environ. Man. 2009, 90, 3185-3196. [CrossRef] [PubMed]

48. Barker, R.; Dawe, D.; Tuong, T.P.; Bhuiyan, S.I.; Guerra, L.C. The outlook for water resources in the year 2020: Challenges for research on water management in rice production. Int. Rice Com. Newslet. 2000, 49, 7-21.

49. NCCC (National Coordination Committee on Climate Change). The People's Republic of China National Greenhouse Gas Inventory of 2005; China Environmental Science Press: Beijing, China, 2014.

50. Ferreira, A.F.; Ribau, J.P.; Silva, C.M. Energy consumption and $\mathrm{CO}_{2}$ emissions of potato peel and sugarcane biohydrogen production pathways, applied to Portuguese road transportation. Int. J. Hydr. Energy 2011, 36, 13547-13558. [CrossRef]

51. Pishgar-Komleh, S.H.; Ghahderijani, M.; Sefeedpari, P. Energy consumption and $\mathrm{CO}_{2}$ emissions analysis of potato production based on different farm size levels in Iran. J. Clean. Prod. 2012, 33, 183-191. [CrossRef]

52. Yu, X.R. The Potato Staple Strategy Sessions. Available online: http://news.china.com.cn/txt/2016-02/26/ content_37884056.htm (accessed on 26 February 2016).

53. Qu, D.Y.; Xie, K.Y.; Jin, L.P.; Pang, W.F.; Dian, C.S.; Duan, S.G. Development of potato industry and food security in China. Sci. Agri. Sin. 2005, 38, 358-362, (in Chinese with English abstract).

54. Yang, Y.X.; Wang, G.Z.; Pan, X.C. China Food Composition; Peking University Medical Press: Beijing, China, 2012.

55. Andre, C.M.; Legay, S.; Iammarino, C.; Ziebel, J.; Guignard, C.; Hausman, F.; Evers, D.; Miranda, L.M. The potato in the human diet: A complex matrix with potential health benefits. Potato Res. 2015. [CrossRef] 
56. Gibson, S.; Kurilich, A.C. The nutritional value of potatoes and potato products in the UK diet. Nutr. Bull. 2013, 38, 389-399. [CrossRef]

57. Guo, T. The first step of potato as staple food-remember the first generation of potato food products (30\% potato powder steamed bread). Seed Sci. Technol. 2015, 7, 15-16. 